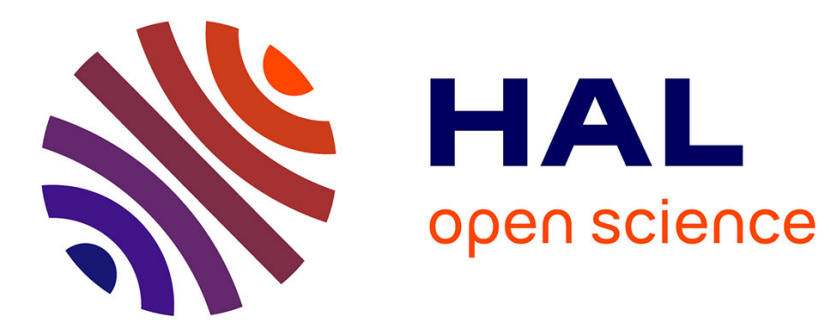

\title{
Methane emissions from boreal and tropical forest ecosystems derived from in-situ measurements
}

\author{
V. Sinha, J. Williams, P. J. Crutzen, J. Lelieveld
}

\section{To cite this version:}

V. Sinha, J. Williams, P. J. Crutzen, J. Lelieveld. Methane emissions from boreal and tropical forest ecosystems derived from in-situ measurements. Atmospheric Chemistry and Physics Discussions, 2007, 7 (5), pp.14011-14039. hal-00303115

\section{HAL Id: hal-00303115 \\ https://hal.science/hal-00303115}

Submitted on 28 Sep 2007

HAL is a multi-disciplinary open access archive for the deposit and dissemination of scientific research documents, whether they are published or not. The documents may come from teaching and research institutions in France or abroad, or from public or private research centers.
L'archive ouverte pluridisciplinaire HAL, est destinée au dépôt et à la diffusion de documents scientifiques de niveau recherche, publiés ou non, émanant des établissements d'enseignement et de recherche français ou étrangers, des laboratoires publics ou privés. 
Atmos. Chem. Phys. Discuss., 7, 14011-14039, 2007

www.atmos-chem-phys-discuss.net/7/14011/2007/

(C) Author(s) 2007. This work is licensed

under a Creative Commons License.

\section{Methane emissions from boreal and tropical forest ecosystems derived from in-situ measurements}

V. Sinha, J. Williams, P. J. Crutzen, and J. Lelieveld

Max Planck Institute for Chemistry, J.J. Becher Weg 27, 55128 Mainz, Germany

Received: 4 September 2007 - Accepted: 13 September 2007

- Published: 28 September 2007

Correspondence to: J. Williams (williams@mpch-mainz.mpg.de)

\section{ACPD}

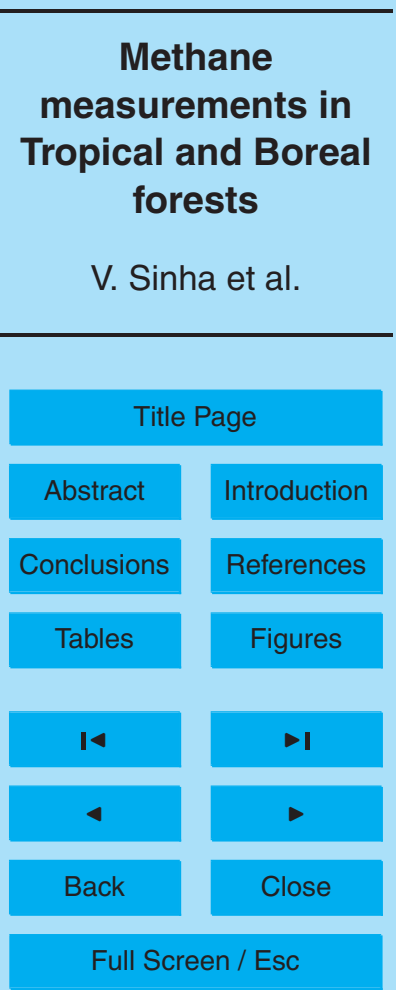

Printer-friendly Version 


\section{Abstract}

Methane is a climatologically important greenhouse gas, which plays a key role in regulating water vapour in the stratosphere and hydroxyl radicals in the troposphere. Recent findings that vegetation emits methane have stimulated efforts to ascertain 5 the impact of this source on the global budget. In this work, we present the results of high frequency (ca. $1 \mathrm{~min}^{-1}$ ) methane measurements conducted in the boreal forests of Finland and the tropical forests of Suriname, in April-May, 2005 and October 2005 respectively. The measurements were performed using a gas chromatograph - flame ionization detector (GC-FID). The average of the median mixing 10 ratios during a typical diel cycle were $1.83 \mu \mathrm{mol} \mathrm{mol}^{-1}$ and $1.74 \mu \mathrm{mol} \mathrm{mol}^{-1}$ for the boreal forest ecosystem and tropical forest ecosystem respectively, with remarkable similarity in the time series of both the boreal and tropical diel profiles. Night time methane emission flux of the boreal forest ecosystem, calculated from the increase of methane during the night and measured nocturnal boundary layer heights yields a 15 flux of $(3.62 \pm 0.87) \times 10^{11}$ molecules cm $\mathrm{cm}^{-2} \mathrm{~s}^{-1}$ (or $45.5 \pm 11 \mathrm{Tg} \mathrm{CH}_{4} \mathrm{yr}^{-1}$ for global boreal forest area). This is a source contribution of circa $8 \%$ of the global methane budget. These results highlight the importance of the boreal and tropical forest ecosystems for the global budget of methane. The results are also discussed in the context of recent work reporting high methane mixing ratios over tropical forests using space borne near infra-red spectroscopy measurements.

\section{Introduction}

Methane is the most abundant hydrocarbon (circa $1.8 \mu \mathrm{mol} \mathrm{mol}^{-1}$ ) in the atmosphere. It has significant implications for atmospheric chemistry and climate, as it plays a key role in regulating stratospheric water vapour and tropospheric hydroxyl radicals (Khalil, 2000). Atmospheric methane mixing ratios have nearly tripled since pre-industrial times (Prather et al. 2001; IPCC 2001), and while it is generally agreed that approxi-

\section{Methane measurements in Tropical and Boreal forests}

V. Sinha et al.

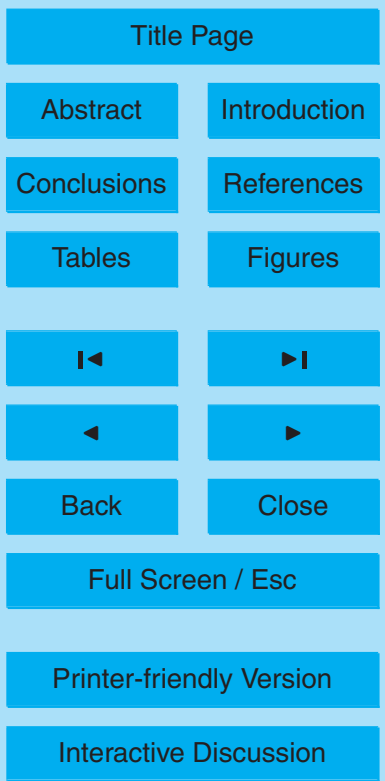


mately $600 \mathrm{Tg} \mathrm{CH}_{4} \mathrm{yr}^{-1}\left(1 \mathrm{Tg}=10^{12} \mathrm{~g}\right)$ is released to the atmosphere globally, estimates of some of the individual source and sink terms within the global budget are rather uncertain (Lelieveld et al., 1998). For example, the range of the emission estimates for wetlands, the single largest natural methane source, is $92-232 \mathrm{Tg} \mathrm{CH}_{4} \mathrm{yr}^{-1}$ with a 5 best guess estimate of $145 \mathrm{Tg} \mathrm{CH}_{4} \mathrm{yr}^{-1}$ (Wuebbles et al., 2002; Matthews et al., 2000; Prather et al., 2001). With such uncertainties in the existing global budget of methane, the discovery that terrestrial plants emit methane under aerobic conditions (Keppler et al., 2006) and reports of enhanced methane emissions from Siberian thaw lakes (Walter et al., 2006), have reinvigorated efforts to better constrain sources and sinks.

10 The global estimate of a $62-236 \mathrm{Tg} \mathrm{CH}_{4} \mathrm{yr}^{-1}$ vegetation source by Keppler et al. (2006), was based on an extrapolation of incubation chamber measurements using the metric of net primary productivity (NPP) for various ecosystems, and subsequent studies (Butenhoff and Khalil, 2007; Houweling et al., 2006; Ferreti et al., 2006; Kirschbaum et al., 2006; Parsons et al., 2006), have presented revised upper limit 5 estimates in the range of $60-176 \mathrm{Tg} \mathrm{CH}_{4} \mathrm{yr}^{-1}$, based on alternative up-scaling approaches. Very recently, using ${ }^{13} \mathrm{C}$ and a laser based measuring technique, Dueck et al. (2007) found no evidence of substantial aerobic methane emissions from terrestrial plants and concluded that the contribution of the new terrestrial plant source is very small at best. As the underlying production mechanism is still unknown, any 20 extrapolation to the global scale is highly speculative. Reanalysis and potential reinterpretation of methane measurements conducted in Venezuela (Crutzen et al., 2006; Sanhueza et al., 2006) concluded that tropical savannah vegetation may also emit methane. Using space borne near infra-red remote sensing by the scanning imaging absorption spectrometer for atmospheric chartography (SCHIAMACHY), Frankenberg et al. (2005) observed almost $40 \mathrm{nmol} / \mathrm{mol}$ higher mixing ratios of methane over tropical rainforests compared to values predicted by a global 3D transport model (TM3) for the period October-November, 2003. Space borne measurements provide greater spatial coverage compared to local in-situ measurements at surface sites, which are closer to sources and sinks. On the other hand, the column averaging employed in volume

\section{Methane measurements in Tropical and Boreal forests}

V. Sinha et al.

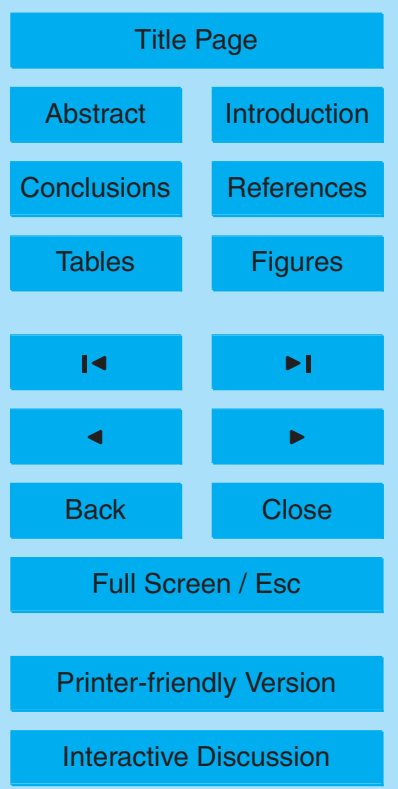

14013 
mixing ratio (VMR) retrievals of space borne measurements, has potential offsets and biases (Bergamaschi et al., 2007; Frankenberg et al., 2006), rendering remote sensing measurements less precise and less accurate than in-situ field measurements. A combination of in-situ and satellite retrieved methane measurements from forested regions

5 therefore appears to be an ideal approach to assess the vegetative methane emission. However, such in-situ data (i.e. real time diel profiles of methane) from the boreal and tropical forests are surprisingly sparse, even though boreal and tropical forests collectively represent almost 76 percent of all forested land and hence have a large potential impact on the global methane budget.

10 In this study, we present the results from a high frequency gas chromatograph equipped with a flame ionization detector (GC-FID). Measurements were taken approximately every minute within a boreal forest ecosystem in Finland and a tropical forest ecosystem in Suriname in April-May, 2005 and October 2005 respectively. We discuss trends in the diel profiles, calculate the nighttime ecosystem flux for the boreal

\section{Experimental}

\subsection{Site description: Boreal forest}

Measurements were conducted from 16 April to 1 May 2005, as part of the BACCI/QUEST III campaign near $(<100 \mathrm{~m})$ the SMEAR II measurement station (Station for Measuring Forest Ecosystem- Atmosphere Relations) in Hyytiäla, southern Finland $\left(61^{\circ} 51^{\prime} \mathrm{N}, 24^{\circ} 17^{\prime} \mathrm{E}, 170 \mathrm{~m}\right.$ a.s.l.). About $600 \mathrm{~m}$ to the south west of the measurement station, there is an oblong lake (circa $2 \mathrm{~km}$ long). Figure 1a shows a picture of the boreal forest vegetation in the vicinity of the measurement tower. In addition to routinely measured meteorological parameters such as wind direction, wind speed etc., the SMEAR II station also conducts tower based measurements of gases such as $\mathrm{CO}_{2}$ and $\mathrm{O}_{3}$ throughout the year, providing a comprehensive suite of supporting

\section{Methane measurements in Tropical and Boreal forests}

V. Sinha et al.

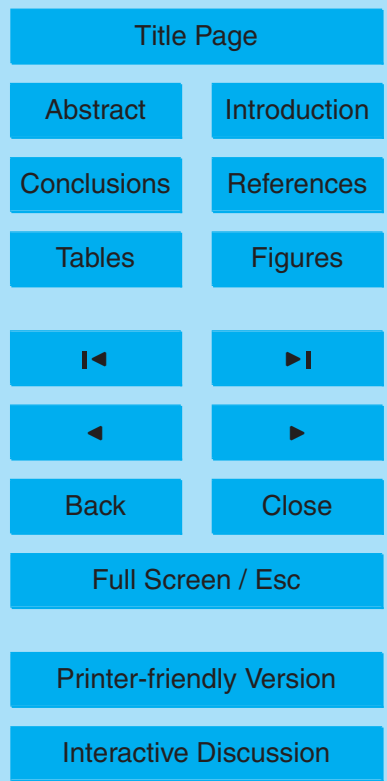

EGU 
measurements as detailed in Hari and Kulmala (2005) and Vesala et al. (1998). A detailed distribution of the different land use categories in a $1600 \mathrm{~km}^{2}$ area around the SMEAR II station has been described recently in Haapanala et al. (2007) using data derived from satellite photographs and forest inventories of the National Land Survey 5 of Finland. The $1600 \mathrm{~km}^{2}$ area around the SMEAR II station has spruce dominated forest (Picea abies; 25.5\%), pine dominated forest (Pinus sylvestris; $22.7 \%$ ), mixed forest (European aspen: Populus tremula and Birch: Betula pendula and pubescens; $20.9 \%)$, deciduous forest $(2 \%)$, agriculture $(10.2 \%)$, wetlands $(0.7 \%)$ and water bodies $(13 \%)$. The Scots pine forest was planted in 1964 and in 2004 the canopy height was 10 around $14 \mathrm{~m}$ (Rinne et al., 1999; Hari and Kulmala, 2005).

Figure 2 shows the wind rose plot for the period of our study in Hyytiäla. During the campaign the wind blew mostly from the $0^{\circ}-135^{\circ}$ and $315^{\circ}-360^{\circ}$ wind sectors. Wind speeds were generally less than $1 \mathrm{~m} \mathrm{~s}^{-1}$, although occasionally they reached up to $1.5 \mathrm{~m} \mathrm{~s}^{-1}$. Our study was conducted in April-May, which marks the transition 15 from winter to spring as the ground begins to thaw and the temperature increases marking the onset of photosynthetic activity (Suni et al., 2003). The minimum and maximum temperatures during the period of our study were around $-5^{\circ} \mathrm{C}$ (typically at circa 06:00 local time LT) and $11^{\circ} \mathrm{C}$ (typically at circa 14:00 LT), with no well defined increasing trend, from the first to the last day of the study.

20 The annual mean temperature at the site is $3^{\circ} \mathrm{C}$. The warmest month is July with a mean temperature of $16^{\circ} \mathrm{C}$ and the coldest is February with mean temperature of $-8^{\circ} \mathrm{C}$. Detailed long term climatic data for the site is available in Drebs et al. (2002).

\subsection{Site description: Tropical forest}

High frequency methane measurements were also conducted using the same in25 strument, within the nature reserve of Brownsberg $\left(4^{\circ} 56^{\prime} \mathrm{N}, 55^{\circ} 10^{\prime} \mathrm{W}, 512 \mathrm{~m}\right.$ a.s.I.), Suriname from 5-14 October, 2005, as part of the Guyana Atmosphere-Biosphere exchange and Radical Intensive Experiment with the Learjet (GABRIEL) campaign. Brownsberg is situated around $120 \mathrm{~km}$ inland and is topographically elevated with re-

\section{Methane measurements in Tropical and Boreal forests}

V. Sinha et al.

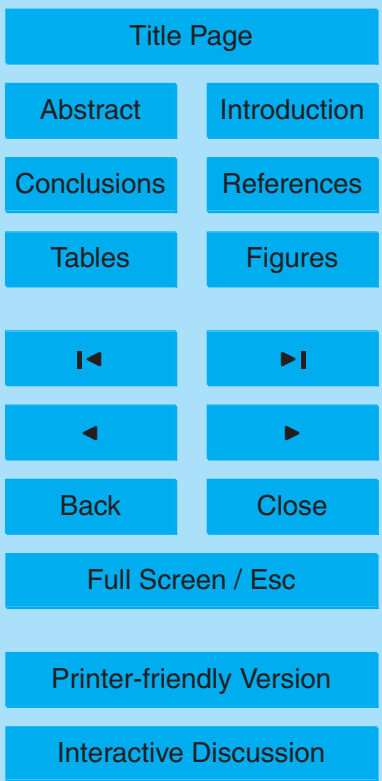


spect to the Brokopondo lake (circa $40 \mathrm{~km}$ long), which lies south east of the measuring site. Figure $1 \mathrm{~b}$ gives a view of the vegetation from Brownsberg where the canopy height was typically around $40 \mathrm{~m}$. Rainforest vegetation is too diverse to be classified in terms specific plant types, however, based on the United States Geological Survey (USGS) 5 world vegetation maps, the main general vegetation types in the area are lowland evergreen broad leaf trees, semi-evergreen moist broadleaf trees and some schlerophyllus dry forest trees. Upwind from the site is $300-400 \mathrm{~km}$ of pristine rainforest before the coast of French Guyana. During October, Suriname experiences the long dry season, in which steady south easterly winds advect clean marine air westwards over the rain10 forest. Typically, the range of temperatures experienced during this period is between $20^{\circ} \mathrm{C}-32^{\circ} \mathrm{C}$.

\subsection{Sampling procedure and measurements:}

Ambient forest air was sampled within the canopy, at heights of $8.5 \mathrm{~m}$ and $35 \mathrm{~m}$ for the boreal and the tropical forests respectively. Employing the same sampling pro15 cedure for both sites, ambient air was drawn rapidly (circa $6 \mathrm{~L} \mathrm{~min}{ }^{-1}$; inlet residence time $<12 \mathrm{~s}$ ) and continuously through $0.64 \mathrm{~cm}$ diameter and $25 \mathrm{~m}$ long shrouded Teflon tubing using an external pump (Rietschle Thomas, Memmingen $\mathrm{GmbH}$, Memmingen). From this main flow of $\sim 6 \mathrm{~L} \mathrm{~min}^{-1}, 1.2 \mathrm{~L} \mathrm{~min}^{-1}$ was drawn continuously by an internal pump within the methane instrument, which is a commercial gas chromatograph 20 equipped with a flame ionization detector (GC-FID) (Model 55C Hydrocarbon Analyzer, Thermo Electron Corporation, Massachusetts, USA). Nitrogen was used as carrier gas while hydrogen and zero air were used as fuel for the FID detector. Central to the instrument's operation is an eight port, two position, rotary valve which is used to introduce the gas sample into the analyzer and to control the flow of gases through the chromatographic column. The operational temperature of this column is $65^{\circ} \mathrm{C}$. After separation from other airborne components within the column, the methane peak is measured by the FID and the signal area is converted into a mixing ratio by comparison with the signal produced by a calibration gas $\left(3.96 \mu \mathrm{mol} \mathrm{mol}^{-1}\right.$ methane standard

\section{Methane measurements in Tropical and Boreal forests}

V. Sinha et al.

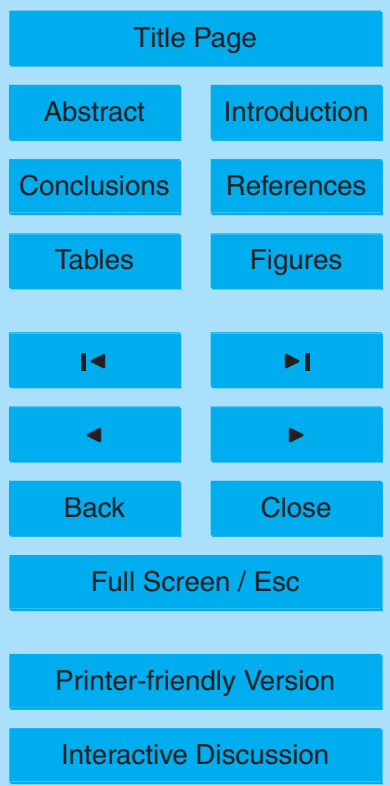


procured from Westfalen AG, Germany; stated accuracy $2 \%$ ). The detection limit of the instrument is $20 \mathrm{nmol} \mathrm{mol}^{-1}$ methane and the measurement range is $0-20 \mu \mathrm{mol} \mathrm{mol}^{-1}$ methane, over which the detector responds linearly. One measurement was taken approximately every $70 \mathrm{~s}$ (frequency of measurements $=0.014 \mathrm{~Hz}$ ).

5 The accuracy and precision errors are each $\pm 2 \%$ of the measured value. However, for the data presented here, the overall uncertainty has been determined as $2.58 \%$, comprising of the $2 \%$ accuracy error (a systematic error which is the same for all measurements) and a reduced precision error of $0.58 \%$ for each data point due to the 15 min time averaging employed in preparing the box and whisker plots (Figs. 3 and 4).

In order to check for instrumental drifts, all the basic instrumental operational parameters such as the oven temperature, column temperature and support gas pressures were monitored continuously, in addition to regular in-field calibrations performed at the start, middle and end of the measurement campaigns.

At the SMEAR II station, carbon dioxide was measured using an infrared light ab15 sorption analyser (URAS $4 \mathrm{CO}_{2}$, Hartmann \& Braun, Frankfurt am Main, Germany) while the wind speed and wind direction were measured with an ultrasonic anemometer (Ultrasonic anemometer 2D, Adolf Thies GmbH, Göttingen, Germany).

\section{Results}

\subsection{Boreal forest: trends in methane mixing ratios and diel cycle}

Methane mixing ratios were highest when the winds were blowing from the north, which has extensive forest cover and low population (Hari and Kulmala et al., 2005). In order to minimise influences from anthropogenic emissions (from the city of Tampere south east of the site), and from wetlands (primarily south west of the site, Haapanala et al., 2007), the methane data was filtered to include data only from the $315^{\circ}-45^{\circ}$ wind in Fig. 3. As per convention, the box encloses all values from the $25-75$ percentile

\section{Methane measurements in Tropical and Boreal forests}

V. Sinha et al.

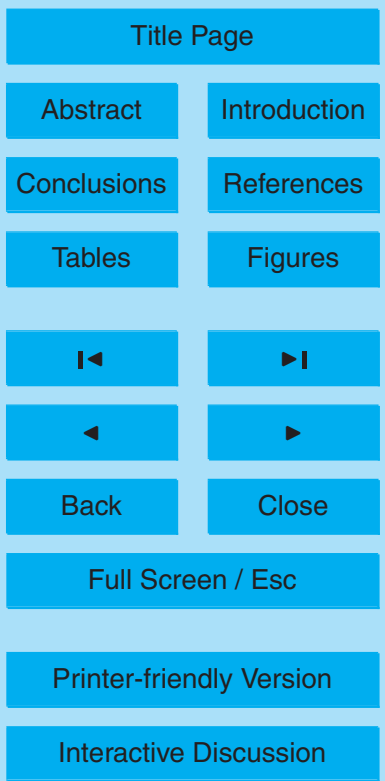


while the whiskers encompass all values in the 5-95 percentile range. It can be seen that the median and mean values compare closely most of the time, indicating that no sharp bursts of methane emissions were detected. The plot also shows a distinct diel variation in the mixing ratios of methane, with lowest median values of around 1.81 $5 \mu \mathrm{mol} \mathrm{mol}^{-1}$ occurring typically between 15:00-16:00 LT and the highest median mixing ratios of the day $\left(\sim 1.85 \mu \mathrm{mol} \mathrm{mol}^{-1}\right)$ occurring at around 06:00 LT. Variability in the methane mixing ratios during the campaign was seen to be least for the measurements between 16:00 and 18:00 LT and higher during the early morning hours. Also evident is a steady increase in the median methane mixing ratios from around 20:00 LT in 10 the evening (just after sunset) till 06:00 LT in the morning (just before sunrise). The average of the median mixing ratios during a typical diel cycle was $1.83 \mu \mathrm{mol} \mathrm{mol}^{-1}$.

\subsection{Tropical forest: Trends in methane mixing ratios and diel cycle}

Figure 4 shows a box and whisker plot derived from the continuous 8700 high frequency $(0.014 \mathrm{~Hz})$ measurements conducted in Brownsberg from 5-14 October, 2005. 15 The median mixing ratios of methane again show a clear diel variation. The median mixing ratios were highest $\left(\sim 1.76 \mu \mathrm{mol} \mathrm{mol}^{-1}\right)$ from 06:30 to 08:00 LT in the morning, and lowest $\left(\sim 1.72 \mu \mathrm{mol} \mathrm{mol}^{-1}\right)$ from 14:30 to $16: 00 \mathrm{LT}$ in the afternoon. Variability is comparatively higher between 16:30 and 19:00 LT. Median and mean values again differ only slightly, except between 19:30 to 20:30 LT, when the difference is almost 20 $10 \mathrm{nmol} \mathrm{mol}^{-1}$. Remarkably, the median methane mixing ratios show a distinct increase from 19:45 LT in the evening till around 05:45 $L T$ in the morning. The average of the median mixing ratios during a typical diel cycle at Brownsberg was $1.74 \mu \mathrm{mol} \mathrm{mol}^{-1}$.

\subsection{Determining the night time methane flux for the boreal forest ecosystem}

In order to calculate the nighttime methane flux for the boreal forest using median mixing ratios in the box and whisker diel profile (Fig. 3), it is necessary to measure the nocturnal boundary layer (NBL) growth. Additionally, to establish whether the NBL is

\section{Methane measurements in Tropical and Boreal forests}

V. Sinha et al.

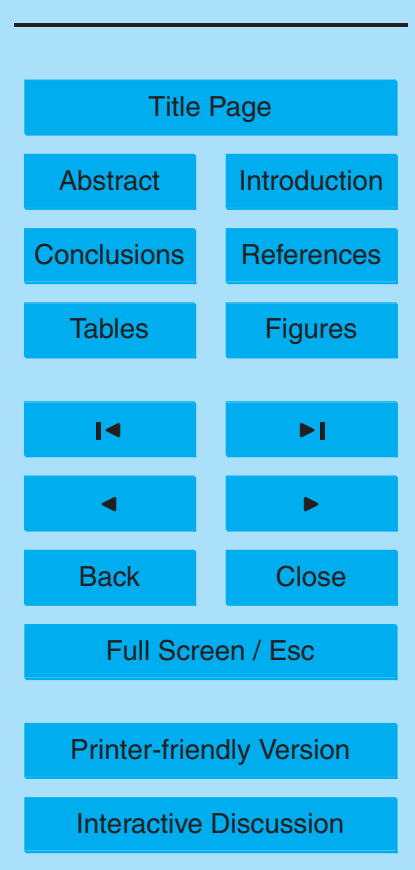

EGU 
well mixed, it is also important to assess whether there is any significant gradient in the vertical profile of methane. In Sect. 3.3.1 we describe how the boundary layer heights were deduced while Sect. 3.3.2 explains how vertical gradients were assessed. Finally, Sect. 3.3.3 details the flux calculation methodology.

\section{3.3.1 Determining the boundary layer height}

Balloon soundings with temperature and humidity sensors were launched (approximately thrice a day) during the campaign to determine the height of the boundary layer. As the height of the boundary layer scales directly with the calculated flux (see Sect. 3.3.3), and is therefore an important step of the flux calculation methodology, we 10 have illustrated how the NBLs were deduced using typical examples in Figs. 5a and $5 \mathrm{~b}$. Figure $5 \mathrm{a}$ shows the vertical profiles of potential temperature and relative humidity measured on 23 April at 07:45 LT while Fig. 5b shows how the boundary layer heights were established from the turning points of the potential temperature vertical profiles at 19:45 LT on 24 April, and 05:45 LT on 25 April, 2005. Table 1 lists the boundary layer height values that were measured in the evening ( 20:00 LT) and the morning ( 06:00 LT), on consecutive days from 24-28 April. From these values the average evening time ( 20:00 LT) boundary layer height was established as $80 \mathrm{~m}$ while the average morning time ( 06:00 LT) boundary layer height was established as $180 \mathrm{~m}$. A gradual growth of this magnitude is in keeping with current understanding of nocturnal boundary layer dynamics (Stull, 1988).

\subsubsection{Assessing vertical gradients}

Vertical gradients within the nocturnal boundary layer (NBL) were assessed using vertical profiles of carbon dioxide made at multiple heights from the SMEAR II measurement tower (heights: $4.2 \mathrm{~m}, 8.4 \mathrm{~m}, 16.8 \mathrm{~m}, 33.6 \mathrm{~m}, 50.4 \mathrm{~m}, 67.4 \mathrm{~m}, 74 \mathrm{~m}$ ) at the start 25 (17 and 18 April), middle (20 and 21 April) and end (30 April and 1 May) of the study period (16 April to 1 May). Carbon dioxide is emitted from the forest at night and has a

\section{Methane measurements in Tropical and Boreal forests}

V. Sinha et al.

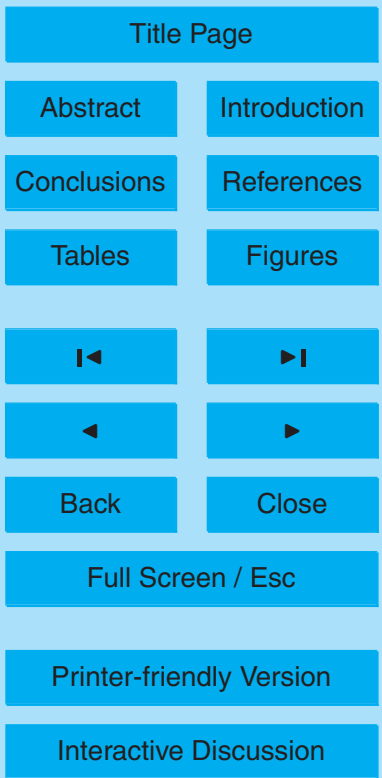


rather long atmospheric lifetime (on the order of several years). Thus within the NBL, the vertical gradients of both methane and carbon dioxide will be driven by physical parameters rather than chemical reactions with other species. Figure 6 shows the carbon dioxide vertical profiles in the evening, when the NBL starts to grow ( 20:00 LT) and in 5 the morning ( 06:00 LT), when it has attained its maximum height. In order to examine gradients with respect to the methane sampling height of $8.5 \mathrm{~m}$, the values in Fig. 6 are represented as a percentage of the carbon dioxide mixing ratio at the $8.5 \mathrm{~m}$ level. It can also be seen in Fig. 6 , that the difference between the highest point and the $8.5 \mathrm{~m}$ level is typically less than $0.3 \%$ and in no case more than $0.5 \%$. This shows that the $10 \mathrm{NBL}$ was well mixed and that mixing ratios measured at the $8.5 \mathrm{~m}$ level can be taken to be representative of the entire mixed NBL, for both carbon dioxide and methane.

\subsubsection{Flux calculation}

Consider a box of cross section area $\mathrm{A} \mathrm{cm}^{2}$ and height $80 \mathrm{~m}$ at 20:00 LT which grows to a height of $180 \mathrm{~m}$ at 06:00 LT. Then using the mass balance approach, the total 15 number of methane molecules in the box at 06:00 LT $\left(\mathrm{N}_{06: 00}\right)$ can be expressed as the contribution of the initial number of methane molecules in the box at 20:00 LT $\left(\mathrm{N}_{20: 00}\right)$, the increase due to the emission flux $\left(\mathrm{F}_{\mathrm{CH} 4}\right)$, assumed to be constant from 20:0006:00 LT, and the contribution of methane molecules due to mixing of residual air from above ( $\mathrm{N}_{\text {Residuallayer }}$ ), as the box grows from $80 \mathrm{~m}$ at 20:00 LT to $180 \mathrm{~m}$ at 06:00 LT.

Expressing the above as an equation we get,

$\mathrm{N}_{06: 00}=\mathrm{N}_{20: 00}+\mathrm{F}_{\mathrm{CH} 4} \times \mathrm{A} \times(36000)+\mathrm{N}_{\text {ResidualLayer }}$

Where,

$$
\begin{aligned}
& \mathrm{N}_{06: 00}=\mathrm{CH}_{4}[\mathrm{t}=06: 00] \times \text { C.F. } \times \mathrm{A} \times 18000 ; \\
& \mathrm{N}_{20: 00}=\mathrm{CH}_{4}[\mathrm{t}=20: 00] \times \text { C.F. } \times \mathrm{A} \times 8000 ; \\
& \mathrm{N}_{\text {ResidualLayer }}=\mathrm{CH}_{4}[\text { avg. b/w 16:00 LT and 19:00 LT] } \times \text { C.F. } \times \mathrm{A} \times 10000 ; \\
& \text { C.F. is the factor used for converting nmol mol }{ }^{-1} \text { to molecules } \mathrm{cm}^{-3}=2.69 \times 10^{10} ;
\end{aligned}
$$$$
\text { and from Fig. 3, }
$$

\section{Methane measurements in Tropical and Boreal forests}

V. Sinha et al.

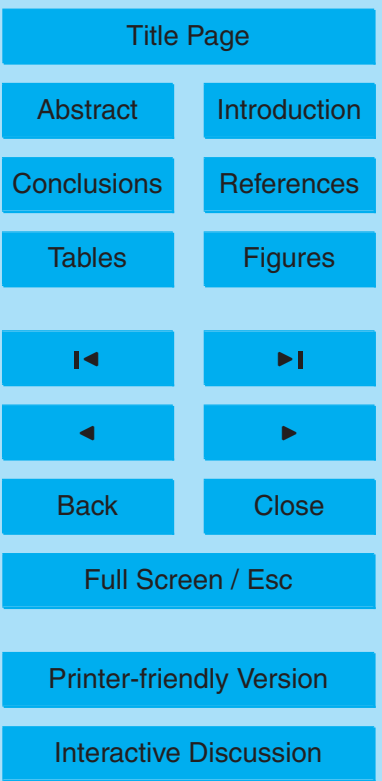


$\mathrm{CH}_{4}[\mathrm{t}=06: 00]$, the median mixing ratio at 06:00 $\mathrm{LT}=1850 \mathrm{nmol} \mathrm{mol}{ }^{-1}$

$\mathrm{CH}_{4}[\mathrm{t}=20: 00]$, the median mixing ratio at $20: 00 \mathrm{LT}=1820 \mathrm{nmol} \mathrm{mol}^{-1}$

and $\mathrm{CH}_{4}$ [avg. b/w 16:00 and 19:00], the average of median mixing ratios between 16:00 LT and 19:00 LT (assumed to be the residual layer mixing ratio) = $51819 \mathrm{nmol} \mathrm{mol}^{-1}$

Using appropriate values in Eq. (1), we derive a net night time ecosystem emission flux of $3.62 \times 10^{11} \mathrm{CH}_{4}$ molecules $\mathrm{cm}^{-2} \mathrm{~s}^{-1}$.

\section{Discussion}

\subsection{Boreal forest data}

10 Previous work on methane emissions from boreal forest ecosystems has been mainly based in Canada and the United States (Simpson et al., 1999, 1997). At Hyytiäla, a background forest site comprising of more than $80 \%$ vegetation in $1600 \mathrm{~km}^{2}$ of surrounding area (Haapanala et al., 2007), research has been mainly focused on aerosol and emissions of reactive biogenic compounds such as terpenes and oxygenated

15 volatile organic compounds (Kulmala et al., 2004; Tunved et al., 2006; Yassaa and Williams, 2007).

To our knowledge, this is the first time that such high resolution methane diel profiles have been reported from a boreal forest ecosystem, showing night time emission and hence accumulation of methane within the NBL. The atmospheric lifetime of methane is around 8.9 years and so the diel variation at Hyytiäla cannot be explained by the reaction of methane with hydroxyl radicals during daytime. Rather, the diel profile of methane is driven by the dynamics of the boundary layer coupled with biogenic emissions or uptake. After sunset, the ground starts to cool radiatively, causing the growth of a stable nocturnal boundary layer (NBL). Thus there is a decoupling (inhibited gas exchange) of the surface boundary layer from the free troposphere (Stull, 1988). Although during the night the nocturnal boundary layer deepens, mixing ratios

\section{Methane measurements in Tropical and Boreal forests}

V. Sinha et al.

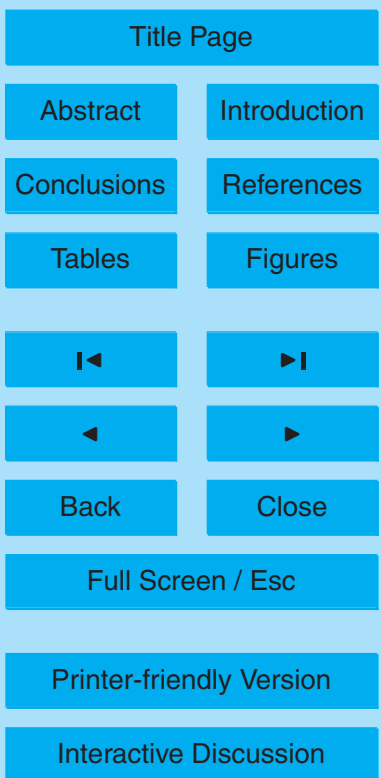


of methane rise through the night clearly indicating an emission. After sunrise, the ground starts to warm and the surface heat flux causes the boundary layer to grow until it reaches its maximum height in the afternoon. The volume of this daytime well mixed layer is greater than the volume of the well mixed NBL, and the dilution effect 5 of air from above overwhelms the emissions during the day, leading to a daytime decrease in the volume mixing ratio of methane (see Fig. 3). When compared with three month averaged mixing ratios for April-June, 2003 of circa $1.75 \mu \mathrm{mol} \mathrm{mol}^{-1}$ methane over Hyytiäla (Fig. 5 in Bergamaschi et al., 2007) based on SCHIAMACHY measurements, the value of $1.83 \mu \mathrm{mol} \mathrm{mol}^{-1}$ presented here for 2005 is almost $80 \mathrm{nmol} \mathrm{mol}^{-1}$ 10 higher. The flux of circa $4 \mathrm{mg}$ methane $\mathrm{m}^{-2}$ day $^{-1}\left(1.74 \times 10^{11}\right.$ molecules $\left.\mathrm{cm}^{2} \mathrm{~s}^{-1}\right)$ reported in the same work is also considerably smaller in comparison to our night time flux of $3.62 \times 10^{11}$ molecules $\mathrm{cm}^{2} \mathrm{~s}^{-1}$. One explanation for this difference could be that source strengths may have increased in 2005 compared to 2003, as the sink due to $\mathrm{OH}$ is unlikely to have changed by factor of 2, between 2003 and 2005. Alternatively, 15 it might be that potential offsets and biases in the SCHIAMACHY (Frankenberg et al., 2006; Bergamaschi et al., 2007) retrieval scheme cause it to underestimate methane over Hyytiäla.

The boreal forest ecosystem has been previously reported as both a net sink and a net source, for methane. However, this has not been well character20 ized. While Tyler (1991) and Steudler et al. (1989) reported a sink for the boreal forest ecosystem, Simpson et al. (1997) reported a net emission flux of 0.8$1.05 \times 10^{11}$ molecules $\mathrm{cm}^{-2} \mathrm{~s}^{-1}$ (mixing ratio circa $1.82-1.90 \mu \mathrm{mol} \mathrm{mol}^{-1}$ ) from a boreal forest ecosystem in Saskatchewan during springtime (April-September, 1994) using micrometeorological tower measurements. Reports of the boreal forest as a net sink for methane are almost exclusively based on data from chamber measurements (Savage et al., 1997; Schiller and Hastie et al, 1996; Whalen et al., 1992). Simpson et al. (1999) suggested that the apparent discrepancy is most probably because chamber measurements are conducted close to the surface and are influenced strongly by the soil, which is known to uptake methane. Further, Simpson et al. (1997) reported

\section{ACPD}

7, 14011-14039, 2007

\section{Methane measurements in Tropical and Boreal forests}

V. Sinha et al.

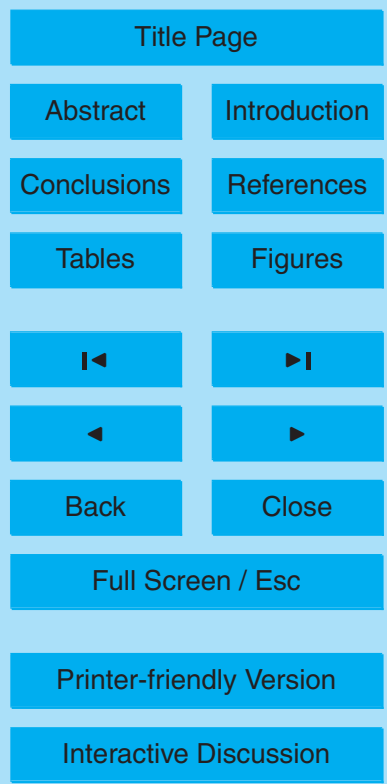


that micrometeorological measurements conducted only at the base of the tower indicated the forest to be a sink while overall, the forest was found to be a net source of methane.

As detailed in Khalil (2000) and references therein, methane emissions can vary con5 siderably based on seasonality, land use and environmental parameters such as soil temperature and water table levels. Nevertheless, bottom up estimates using in-situ field measurements are useful to get an idea about the possible contribution of particular ecosystem types to the global budget. Extrapolating the net night time methane emission flux of $3.62 \times 10^{11}$ molecules $\mathrm{cm}^{-2} \mathrm{~s}^{-1}$ derived in this work, to the global boreal 10 forest area of $1.5 \times 10^{17} \mathrm{~cm}^{2}$ (Tunved et al., 2006), we estimate an annual boreal forest ecosystem flux of $45.5 \mathrm{Tg} \mathrm{CH}_{4} \mathrm{yr}^{-1}$. This is around $7.5 \%$ of the estimated global $600 \mathrm{Tg}$ $\mathrm{CH}_{4} \mathrm{yr}^{-1}$ released into the atmosphere. It should be noted however, that this flux calculation methodology is rather sensitive to the NBL estimates. Based on the NBL height variability observed at Hyytiäla (see Table 1), this introduces an uncertainty of up to $15 \pm 25 \%$ for the calculated flux.

From our data, it is not possible to derive an accurate boreal vegetation flux as the measured flux is a net ecosystem flux. However for the planning of future studies that seek to derive the vegetation flux using in situ field measurements, and to illustrate the challenge inherent in obtaining a field estimate of emissions only due to vegetation, we discuss herein a land use based approach which would help to constrain the source contribution of vegetation to the global methane budget, using in-situ field measurements from different forest ecosystem types. This would be especially useful, since the laboratory based up scaling estimates as well as the subsequent model estimates, for the contribution of the new source discovered by Keppler et al. (2006) have considerable uncertainty.

Average fluxes compiled by Bartlett and Harriss (1993) for broad ecosystem types show that values for the boreal wetlands are between 3.7-4.1x $10^{12}$ molecules $\mathrm{cm}^{-2} \mathrm{~s}^{-1}$ (or $87-96 \mathrm{ng} \mathrm{m}^{-2} \mathrm{~s}^{-1}$ ). The average methane emission flux, from southern boreal lakes (located between $60^{\circ} 57^{\prime}, 24^{\circ} 27^{\prime}$ and $61^{\circ} 22^{\prime}$,

\section{Methane measurements in Tropical and Boreal forests}

V. Sinha et al.

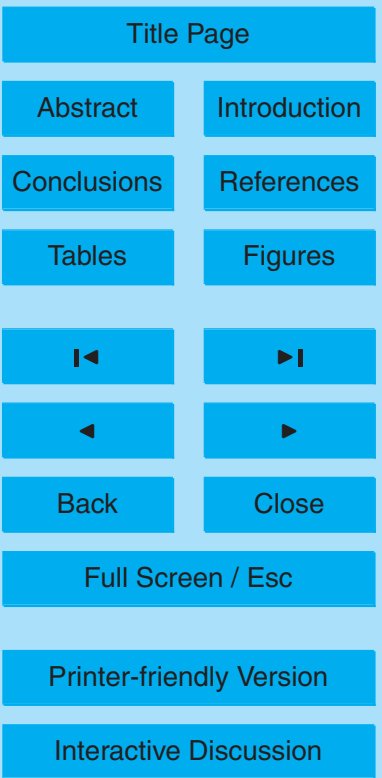


$25^{\circ} 15^{\prime}$ ) for the growing seasons of April-September (years 1998-2002), is $2.15 \times 10^{12}$ molecules $\mathrm{cm}^{-2} \mathrm{~s}^{-1}$ (Bergstrom et al., 2006). Thus a wetland flux of $4.1 \times 10^{12}$ molecules $\mathrm{cm}^{-2} \mathrm{~s}^{-1}$ and lake emission flux of $2.15 \times 10^{12}$ molecules cm $\mathrm{cm}^{-2} \mathrm{~s}^{-1}$ can be considered as generous estimates for wetland and lake emissions in Hyytiäla $5\left(61^{\circ} 51^{\prime} \mathrm{N}, 24^{\circ} 17^{\prime} \mathrm{E}\right)$ during April-May. Knowing that wetlands and water bodies make up $0.7 \%$ and $13 \%$ of the $1600 \mathrm{~km}^{2}$ footprint area around the measurement site (Sect. 2.1) a conservative estimate of the boreal vegetation can be calculated as follows:

Wetlandflux + Lakeflux + Vegetationflux $=$ Net ecosystem flux

10 That is,

$0.7 \%$ of $4.18 \times 10^{12}$ molecules $\mathrm{cm}^{-2} \mathrm{~s}^{-1}+13 \%$ of $2.15 \times 10^{12}$ molecules $\mathrm{cm}^{-2} \mathrm{~s}^{-1}+$ Vegetation flux $=3.62 \times 10^{11}$ molecules $\mathrm{cm}^{-2} \mathrm{~s}^{-1}$

Solving the above yields a boreal vegetation flux of $5.32 \times 10^{10}$ molecules $\mathrm{cm}^{-2} \mathrm{~s}^{-1}$. Upscaling for the global boreal forest area of $1.5 \times 10^{17} \mathrm{~cm}^{2}$ (Tunved et al., 2006), the contribution of boreal vegetation to the total methane budget would be circa $6.7 \mathrm{Tg}$ $\mathrm{CH}_{4} \mathrm{yr}^{-1}$. Note that this is a highly uncertain estimate because the contribution of the individual components in Eq. (2) are in themselves quite uncertain, and were not measured concurrently with the methane measurements of this study, and even a circa $1 \%$ change in the flux value used for wetlands would render the boreal vegetation flux negligible. It should also be noted that an estimate based on such an approach would probably be a lower range estimate because according to Keppler et al. (2006) plants emit 2-5 fold more methane during the day, so that the net ecosystem flux might actually be higher if day time emissions could be included.

Thus, as reiterated earlier, based on the data obtained in this study, we can neither confirm nor disprove whether boreal vegetation emits methane.

Keppler et al. (2006) reported boreal vegetation emissions to be in the range of 1.1-4.1 $\mathrm{Tg} \mathrm{CH}_{4} \mathrm{yr}^{-1}$, based on the upscaling metric of net primary productivity (NPP). Using the metrics of leaf mass index and photosynthesis rates for different biomes,

\section{ACPD}

7, 14011-14039, 2007

\section{Methane \\ measurements in \\ Tropical and Boreal \\ forests}

V. Sinha et al.

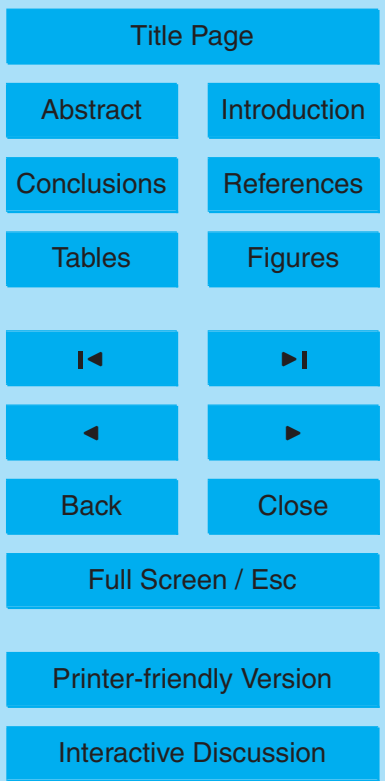


Kirschbaum et al. (2006) upscaled the results of Keppler et al. (2006) and reported boreal vegetation emission estimates of $2.8 \mathrm{Tg} \mathrm{yr}^{-1}$ and $0.6 \mathrm{Tg} \mathrm{yr}^{-1}$, respectively. Emulating the Kirschbaum et al. (2006) approach of biome leaf mass for upscaling, Parsons et al. (2006) revaluated the results of Keppler et al. (2006) and proposed an estimate 5 of $3.6 \mathrm{Tg} \mathrm{CH}_{4} \mathrm{yr}^{-1}$ for boreal vegetation. Thus based on these previous estimates, it appears that boreal vegetation contributes only circa $1 \%$ to the global methane budget. The boreal ecosystem as a whole, however, based the results of this study, contributes almost $7.5 \%$.

\subsection{Tropical forest data}

10 Analogous to the boreal methane profile, the diel profile from Brownsberg (Fig. 4) is also characterized by an increase in the median methane mixing ratios during nighttime. Carmo et al. (2006) and Crutzen et al. (2006) have reported similar profiles from upland amazon forests and mixed tropical savannah grasslands, respectively. Frankenberg et al. (2005) observed enhanced mixing ratios of methane over tropical rainforests and called for in-situ measurements to validate their measurements. It is interesting to note that compared to the SCHIAMACHY measurements of $1.76 \mu \mathrm{mol} \mathrm{mol}^{-1}$ methane, and the global chemistry transport model (TM3) value of $1.72 \mu \mathrm{mol} \mathrm{mol}^{-1}$ for the same season in 2003 over Suriname, the average of all our in situ measurements in 2005 is $1.74 \mu \mathrm{mol} \mathrm{mol}^{-1}$. If we assume that the sources and sinks in 2003 and 2005 were 20 not significantly different, then the in-situ measurements would seem to suggest that the enhanced emissions over the Suriname rainforest are probably not as strong as first reported in Frankenberg et al. (2005). The latter argument is supported by the work of Bergamaschi et al. (2007) that extended the original analysis by Frankenberg et al. (2006), and reported that SCHIAMACHY $\mathrm{CH}_{4}$ retrievals may have some bias (up to $\sim 30 \mathrm{nmol} \mathrm{mol}^{-1}$ ) that depends on latitude and season.

Krejci et al. (2005) have estimated the NBL over the rainforest in Suriname to be less than $250 \mathrm{~m}$. Brownsberg is situated on a hill $(512 \mathrm{~m}$ a.s.l.) and the presence of the nearby Brokopondo lake (also called Prof. Dr. Bloomstein lake) may potentially impact

\section{Methane measurements in Tropical and Boreal forests}

V. Sinha et al.

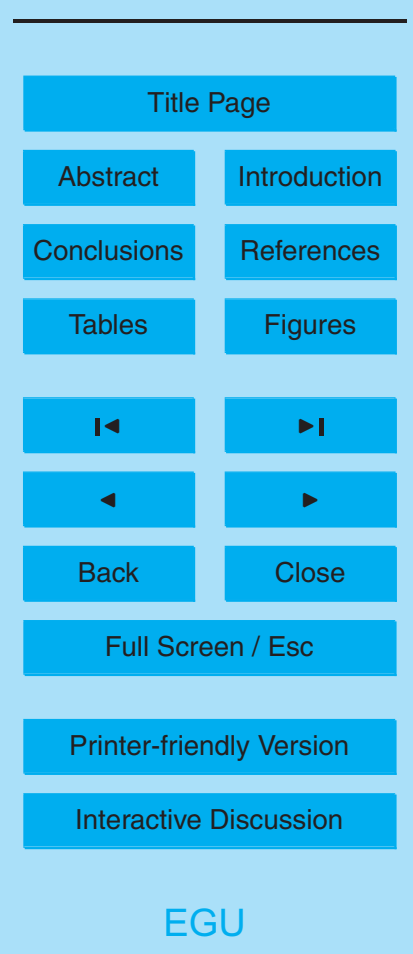


our methane measurements. So while the measurements at Brownsberg (512 m a.s.I.), resemble tower type measurements with respect to the surrounding rainforest, overall the situation presents a less than ideal site for flux measurements. Still for the sake of discussion, if we assume that methane was well mixed within the NBL and that the 5 NBL height over the rain forest was $100 \mathrm{~m}$ at $\sim 19: 45 \mathrm{LT}$ and 200 $\mathrm{m}$ at $\sim 05: 45 \mathrm{LT}$, then applying the method described in Sect. 3.3.3, we would derive a night time emission flux of $3.77 \times 10^{11}$ molecules $\mathrm{cm}^{-2} \mathrm{~s}^{-1}$. Since, vertical potential temperature profiles and meteorological data of the type used for the Hyytiäla site measurements were not available for the tropical forest site, the tropical methane flux has a greater uncertainty 10 and this flux must be interpreted with appropriate care. Previous measurements from the upland forest area $\left(1.5 \times 10^{6} \mathrm{~km}^{2}\right)$ of the Amazon region, by Carmo et al. (2006) have suggested a flux range of $0.96-9.1 \times 10^{11}$ molecules $\mathrm{cm}^{-2} \mathrm{~s}^{-1}$ ( or $4-38 \mathrm{Tg} \mathrm{yr}^{-1}$ ) which is lower than the flux of $\sim 1.2 \times 10^{12}$ molecules $\mathrm{cm}^{-2} \mathrm{~s}^{-1}$ reported recently by Miller et al. (2007) referring to the eastern Amazon basin.

\section{Conclusion and outlook}

The boreal forest ecosystem as a whole is a significant source of methane ( $\sim 5.5 \pm 11 \mathrm{Tg} \mathrm{CH}_{4} \mathrm{yr}^{-1}$ ) and appears to contribute circa $7.5 \%$ to the global methane budget. High temporal resolution measurements, from the boreal forest and tropical forest ecosystems, made over longer time periods are needed to assess methane emissions from these regions more accurately, because based on the short term data presented in this work, it appears that boreal forest ecosystem emissions may be currently underestimated, as SCHIAMACHY data for the same period over Hyytiäla showed methane mixing ratios of $1.75 \mu \mathrm{mol} \mathrm{mol}^{-1}$, while our in-situ measurements were $1.83 \mu \mathrm{mol} \mathrm{mol}^{-1}$ and the methane flux reported in Bergamaschi et al. (2007) of $251.74 \times 10^{11}$ molecules $\mathrm{cm}^{2} \mathrm{~s}^{-1}$ was lower than the flux of $3.62 \times 10^{11}$ molecules $\mathrm{cm}^{2} \mathrm{~s}^{-1}$, obtained in this study. Collectively, the nighttime emissions from boreal and tropical forest ecosystems indicate a global source contribution of circa $100 \mathrm{Tg} \mathrm{CH}_{4} \mathrm{yr}^{-1}$, which

\section{Methane measurements in Tropical and Boreal forests}

V. Sinha et al.

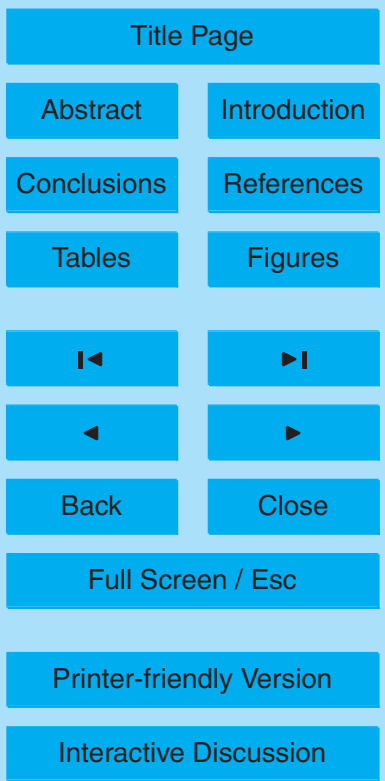


is almost $17 \%$ of the global budget of circa $600 \mathrm{Tg} \mathrm{CH}_{4} \mathrm{yr}^{-1}$. The similarity in the diel methane profiles at such widely different climates is remarkable. Until the mechanism of methane production from plants under aerobic conditions, is better understood, examining net ecosystem fluxes under in-situ natural conditions, would help in constrain-

5 ing the contribution due to a potential new vegetation source and assessing whether their magnitude is of the order of uncertainties in the existing sources, or higher. Although our methane flux estimates refer to nighttime conditions only, whereas aerobic methane production is expected to be larger during daytime, our observations cannot be reconciled with a very large direct methane source of up to 176-236 Tg/yr from the 10 vegetation.

Furthermore, ${ }^{13} \mathrm{C}$ isotope measurements can help to apportion the methane sources in a better manner and thus a combined approach of in-situ measurements at suitable remote and homogeneous sites, remote sensing retrievals and isotope studies would help to reduce the uncertainties in the global methane budget much more effectively.

15 Acknowledgements. We acknowledge M. Kulmala, P. Aalto, L. Kulmala, N. Pimenoff and other members of the Kulmala group at the University of Helsinki for the meteorological and balloon soundings' data and Laurens Ganzeveld for helpful discussions. The authors also thank B. Scheeren and members of the ORSUM group, in particular T. Kluepfel, R. Hofmann, G. Eerdekens, and N. Yassaa for field assistance.

\section{References}

Bartlett, K. and Harriss, R.: Review and assessment of methane emissions from wetlands, Chemosphere, 26, 261-320, 1993.

Bergamaschi, P., Frankenberg, C., Meirink, J. F., Krol, M., Dentener, F., Wagner, T., and Platt, U.: Satellite chartography of atmospheric methane from SCIAMACHY on board ENVISAT:2. Evaluation based on inverse model simulations, J. Geophys. Res., 112, D02304, doi:10.1029/2006JD007268, 2007.

Bergstrom, I., Makelab, S., Kankaalab, P., and Kortelainen, P.: Methane efflux from littoral

\section{ACPD}

\section{Methane measurements in Tropical and Boreal forests}

V. Sinha et al.

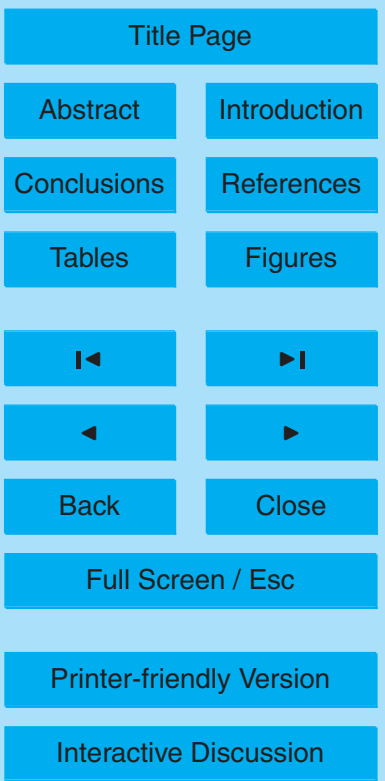


vegetation stands of southern boreal lakes: An upscaled regional estimate, Atmos. Environ., doi:10.1016/j.atmosenv.2006.08.014, 2006.

Butenhoff, C. L. and Khalil, M. A. K., Global methane emissions from terrestrial plants: Environ. Sci. Technol., 41, 4032-4037, 2007.

5 Carmo, J. B., Keller, M., Dias, J. D., Camargo, P. B., and Crill P.: A source of methane from upland forests in the Brazilian Amazon, Geophys. Res. Lett., 33, L04809, doi:10.1029/2005GL025436, 2006.

Crutzen, P. J., Sanhueza, E., and Brenninkmeijer, C. A. M.: Methane production from mixed tropical savanna and forest vegetation in Venezuela, Atmos. Chem. Phys. Discuss., 6, 3093$10 \quad 3097$, http://www.atmos-chem-phys-discuss.net/6/3093/2006/, 2006.

Dueck, T. A., Visser, R., Poorter, H., et al.: No evidence for substantial aerobic methane emission by terrestrial plants: a 13 C-labelling approach: New Phytologist, doi: 10.1111/j.14698137.2007.02103.x, 2007.

Drebs, A., Nordlund, A., Karlsson, P., Helminen, J., and Rissanen, P.: Climatological statistics of 15 Finland 1971-2000, Finnish Meteorological Institute, Helsinki, 99 pp, ISBN 951-697-568-2, 2002.

Ferretti, D. F., Miller, J. B., White, J. W. C., Lassey, K. R., Lowe, D. C., and Etheridge, D. M.: Stable isotopes provide revised global limits of aerobic methane emissions from plants, Atmos. Chem. Phys., 7, 237-241, 2006, http://www.atmos-chem-phys.net/7/237/2006/.

Frankenberg, C., Meirink, J. F., van Weele, M., Platt, U., and Wagner, T.: Assessing methane emissions from global space-borne observations, Science, 308, 1010-1014, 2005.

Frankenberg, C., Meirink, J. F., Bergamaschi, P., Goede, A. P. H., Heimann, M., Korner, S., Platt, U., van Weele, M., and Wagner, T.: Satellite chartography of atmospheric methane from SCIAMACHY on board ENVISAT: Analysis of the years 2003 and 2004, J. Geophys. Res., 111, D07303, doi:10.1029/2005JD006235, 2006.

Haapanala, S., Rinne, J., Hakola, H., Hellen, H., Laakso, L., Lihavainen, H., Janson, R., O'Dowd, C., and Kulmala, M., Boundary layer concentrations and landscape scale emissions of volatile organic compounds in early spring: Atmos. Chem. Phys., 7, 1869-1878, 2007, http://www.atmos-chem-phys.net/7/1869/2007/.

30 Hari, P. and Kulmala, M.: Station for measuring ecosystem-atmosphere relations (SMEAR II), Boreal Environ. Res., 5, 315-322, 2005.

Houweling, S., Rockmann, T., Aben, I., Keppler, F., Krol, M., Meirink, J. F., Dlugokencky, E. J., and Frankenberg , C.: Atmospheric constraints on global emissions of methane from plants,

\section{Methane measurements in Tropical and Boreal forests}

V. Sinha et al.

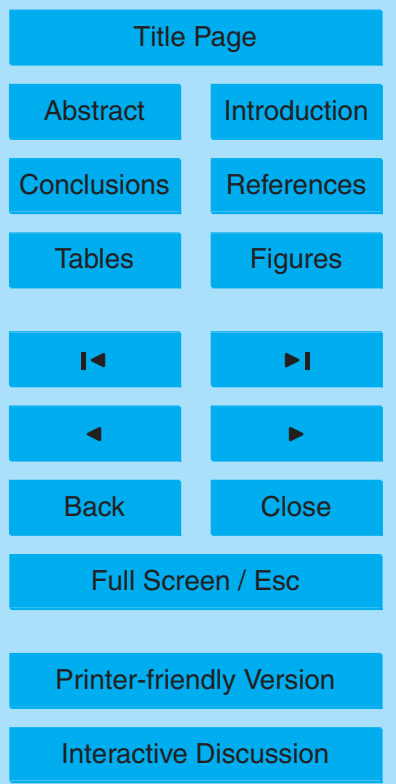


Geophys. Res. Lett., 33, L15821, doi:10.1029/2006GL026162, 2006.

Keppler, F., Hamilton, J. T. G., Brass, M., and Roeckmann, T.: Methane emissions from terrestrial plants under aerobic conditions, Nature, 439, 187-191, 2006.

Kirschbaum, M. U. F., Bruhn, D., Etheridge, D. M., Evans, J. R., Farquhar, G. D., Gifford, R. $5 \quad$ M., Paul, K. I., and Winters, A. J.: A comment on the quantitative significance of aerobic methane release by plants, Funct. Plant. Biol., 33, 521-530, 2006.

Khalil, M. A. K.: Atmospheric methane: an introduction, in: Atmospheric Methane: Its Role in the Global Environment, edited by: M. Khalil, p.p. 1-8, Springer-Verlag, New York, NY, 2000.

Krejci, R., Strom, J., de Reus, M., Williams, J., Fischer, H., Andreae, M. O., and Hansson, H. C.: Spatial and temporal distribution of atmospheric aerosols in the lowermost troposphere over the Amazonian tropical rainforest, Atmos. Chem. Phys., 5, 1527-1543, 2005, http://www.atmos-chem-phys.net/5/1527/2005/.

Kulmala, M., Suni, T., Lehtinen K. E. J., Dal Maso, M., Boy, M., Reissell, A., Rannik, Ü., Aalto, P., Keronen, P., Hakola, H., Back, J., Hoffmann, T., Vesala, T., and Hari, P.: A new feedback mechanism linking forests, aerosols, and climate, Atmos. Chem. Phys., 4, 557-562, 2004, http://www.atmos-chem-phys.net/4/557/2004/.

Lelieveld, J., Crutzen, P., and Dentener, F.: Changing concentration, lifetime and climate forcing of atmospheric methane, Tellus, 50B, 128-150, 1998.

Matthews, E.: Wetlands, in: Atmospheric Methane: Its Role in the Global Environment, edited by: M. Khalil, Springer-Verlag, New York, NY, pp. 202- 233, 2000.

Miller, J. B., Gatti, L. V., d'Amelio, M. T. S., Crotwell, A. M., Dlugokencky, E. J., Bakwin, P., Artaxo, P., and Tans, P. P., Airborne measurements indicate large methane emissions from the eastern Amazon basin: Geophys. Res. Lett., 34, L10809, doi:10.1029/2006GL029213, 2007.

Parsons, A. J., Newton, P.C.D., Clark, H. and Kelliher F. M.: Scaling methane emissions from vegetation, Trends in Ecology and Evolution, doi:10.1016/ j.tree.2006.05.017, 2006.

Prather, M., Ehhalt, D., Dentener, F., Derwent, R., Dlugokencky, E., Holland, E., Isaksen, I., Katima, J., Kirchhoff, V., Matson, P., Midgley, P., and Wang, M.: Atmospheric chemistry and greenhouse gases, Chapter 4, in: Climate Change 2001, The scientific basis: Contribution of working group I to the Third assessment report of the Intergovernmental Panel on Climate, edited by: Houghton, J. T., Ding, Y., Griggs, Y., Noguer, M., v.d. Linden, P. J., Dai, X., Maskell, K., and Johnson, C. A., pp. 881, Cambridge University Press, Cambridge, United Kingdom and New York, NY, US, 2001.

\section{ACPD}

7, 14011-14039, 2007

\section{Methane \\ measurements in \\ Tropical and Boreal \\ forests}

V. Sinha et al.

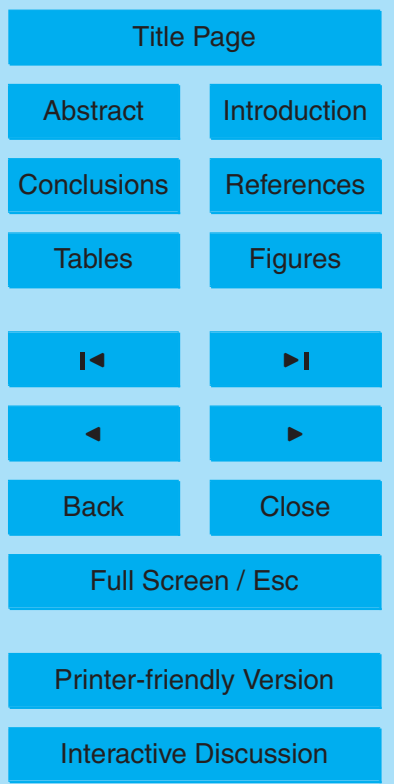


Rinne, J., Hakola, H., and Laurila, T.: Vertical fluxes of monoterpenes above a Scots pine stand in the boreal vegetation zone, Phys. Chem. Earth (B), 24, 711-715, 1999.

Sanhueza, E. and Donoso, L.: Methane emission from tropical savanna Trachypogon sp. grasses, Atmos. Chem. Phys., 6, 5315-5319, 2006,

5 http://www.atmos-chem-phys.net/6/5315/2006/.

Savage, K., Moore, T. R., and Crill, P. M.: Methane and carbon dioxide exchanges between the atmosphere and northern boreal forest soils, J. Geophys. Res., 102, 29279-29 288, 1997.

Schiller, C. L. and Hastie, D. R.: Nitrous oxide and methane fluxes from perturbed and unperturbed boreal forest sites in northern Ontario, J. Geophys. Res., 101(D17), 22 767-22 774, 1996.

Simpson, I. J., Edwards, G. C., Thurtell, G. W., den Hartog, G., and Neumann, H. H., Staebler, R. M.: Micrometeorological measurements of methane and nitrous oxide exchange above a boreal aspen stand, J. Geophys. Res., 102(D24), 29 331-29341, 1997.

Simpson, I. J., Edwards, G. C., and Thurtell, G. W.: Variations in methane and nitrous oxide 15 mixing ratios at the southern boundary of a Canadian boreal forest, Atmos. Environ., 33, 1141-1150, 1999.

Steudler, P. A., Bowden, R. D., Mellico, J. M., and Aber, J. D.: Influence of nitrogen uptake in temperate forest soils, Nature, 341, 314-316, 1989.

Stull, R. B.: An introduction to boundary layer meteorology, Kluwer Academic Publishers, Dordrecht, Netherlands, 1988.

Suni, T., Berninger, F., Vesala, T., Markkanen, T., Hari, P., Mäkelä, A., Ilvesniemi, H., Hänninen, H., Nikinmaa, E., Huttula, T., Laurila, T., Aurela, M., Grelle, A., Lindroth, A., Arneth, A., Shibistova, O., and Lloyd, J.: Air temperature triggers the recovery of evergreen boreal forest photosynthesis in spring, Glob. Change Biol., 9, 1410-1426, 2003.

Tunved, P., Hansson, H.-C., Kerminen, V. M., Strom, J., Dal Maso, M., Lihavainen, H., Viisanen, Y., Aalto, P. P., Komppula, M., and Kulmala, M.: High Natural Aerosol Loading over Boreal Forests, Science, 312, 261-263, 2006.

Tyler, S. C.: The global methane budget, in: Microbial production and consumption of greenhouse gases : methane, nitrogen oxides and halomethanes, edited by: J. E. Rogers and

$30 \quad$ W. B. Whitman, 298 p.p., Am. Soc. for Microbiol., Washington D.C., 1991.

Vesala, T., Haataja, J., Aalto, P., et al.: Long-term field measurements of atmosphere-surface interactions in boreal forest combining forest ecology, micrometeorology, aerosol physics and atmospheric chemistry, Trends in Heat Mass Mom Transf, 4, 17-35, 1998.

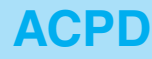

7, 14011-14039, 2007

\section{Methane \\ measurements in \\ Tropical and Boreal \\ forests}

V. Sinha et al.

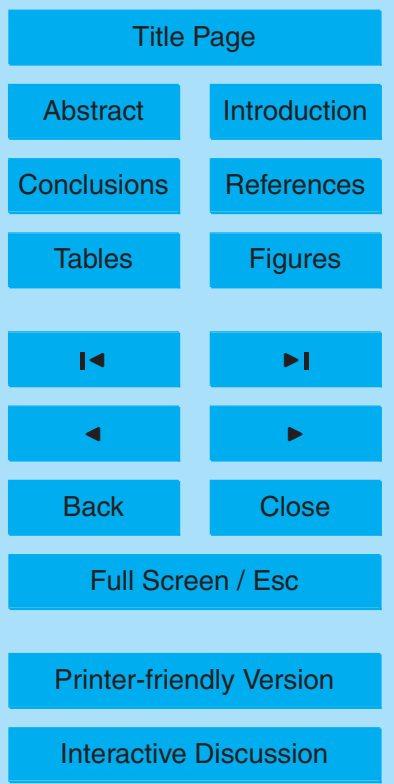


Walter, K. M., Zimov, S. A., Chanton, J. P., Verbyla, D., and Chapin, F. S.: Methane bubbling from Siberian thaw lakes as a positive feedback to climate warming, Nature, 443, 71-75, 2006.

Whalen, S. C., Reeburgh, W. S., and Barber, V. A.: Oxidation of methane in boreal forest soils: a comparison of seven measures, Biogeochemistry, 16(3), 181-211, 1992.

Wuebbles, D. J. and Hayhoe, K.: Atmospheric methane and global change, Earth-Science Reviews, 57, 177-210, 2002.

Yassaa, N. and Williams, J.: Enantiomeric monoterpene emissions from natural and damaged Scots pine in a boreal coniferous forest measured using solid-phase microextraction and gas chromatography/mass spectrometry, J. Chromatogr. A., 1141, 138-144, 2007.

\section{ACPD}

7, 14011-14039, 2007

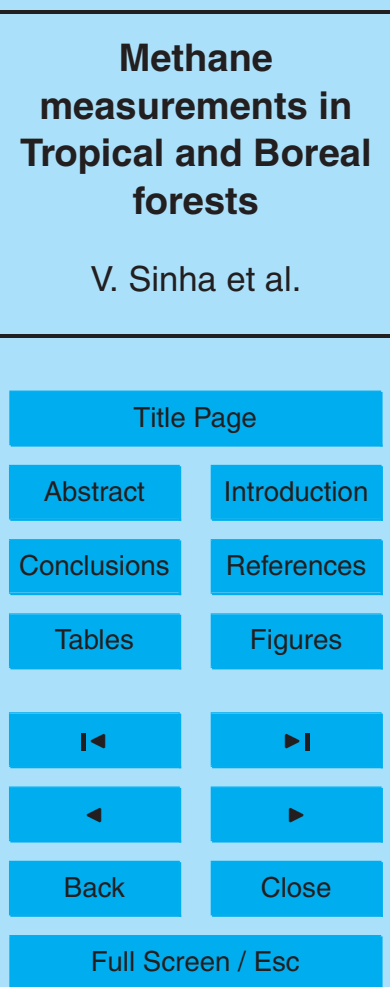

Printer-friendly Version

Interactive Discussion 


\section{ACPD}

7, 14011-14039, 2007

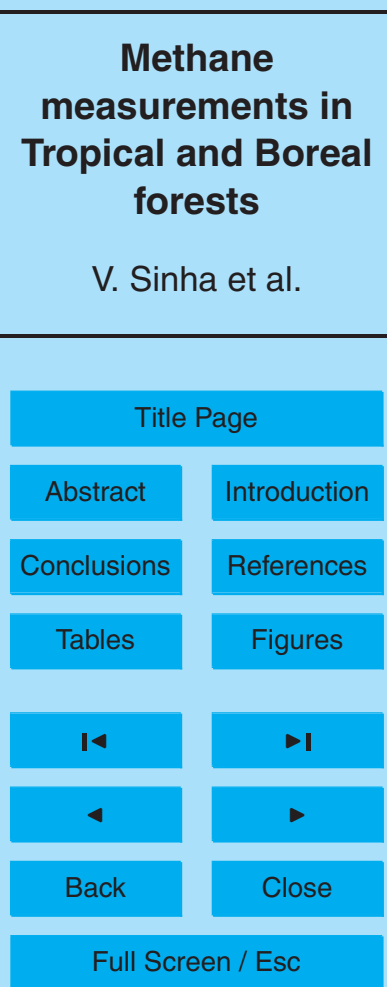

Printer-friendly Version

Interactive Discussion 

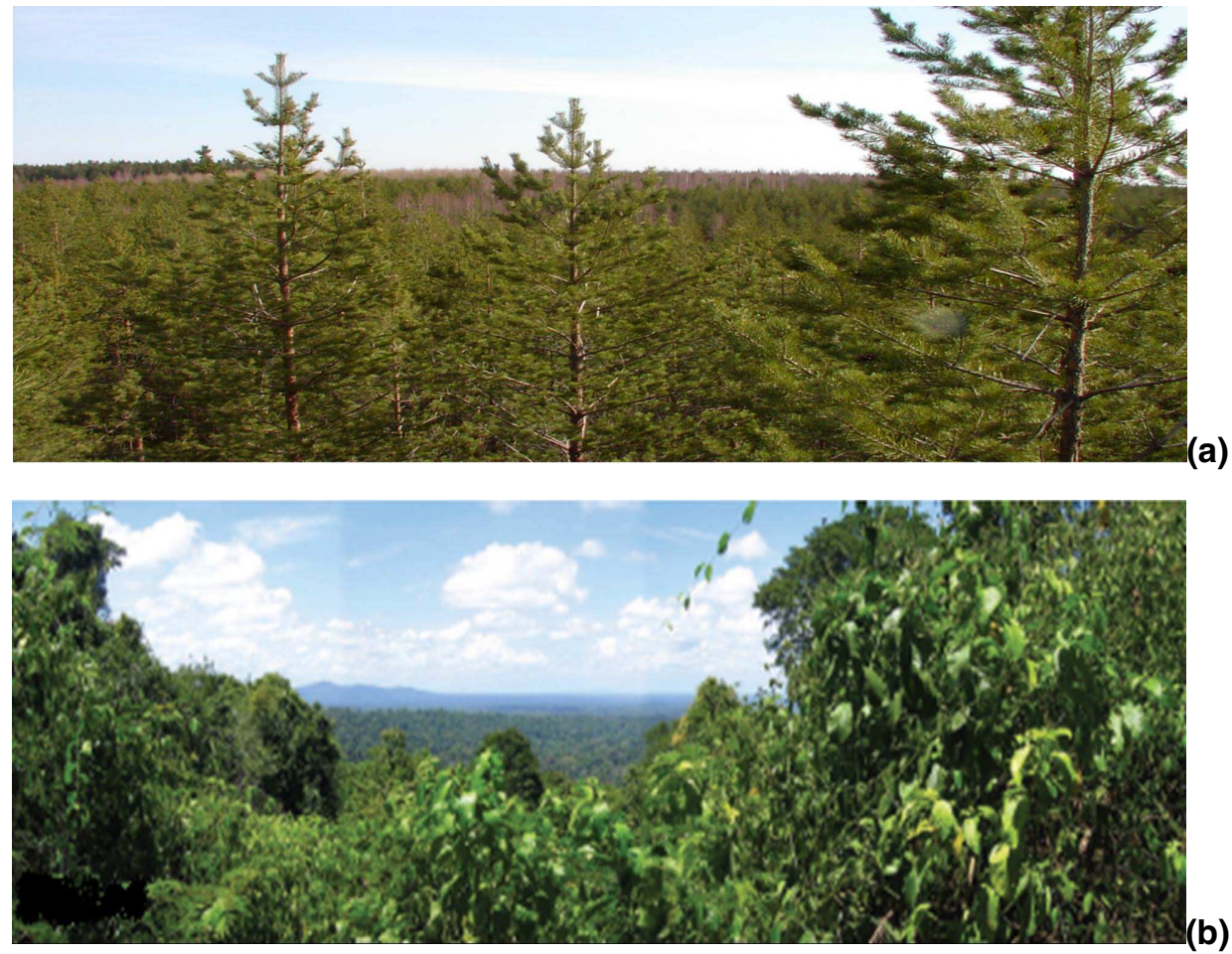

Fig. 1. View of boreal forest vegetation in Hyytiäla $\left(61^{\circ} 51^{\prime} \mathrm{N}, 24^{\circ} 17^{\prime} \mathrm{E}, 170 \mathrm{~m}\right.$ a.s.l.) (above) (a) and view of tropical forest vegetation in Brownsberg $\left(4^{\circ} 56^{\prime} \mathrm{N}, 55^{\circ} 10^{\prime} \mathrm{W}, 514 \mathrm{~m}\right.$ a.s.l.) (below) (b).
ACPD

7, 14011-14039, 2007

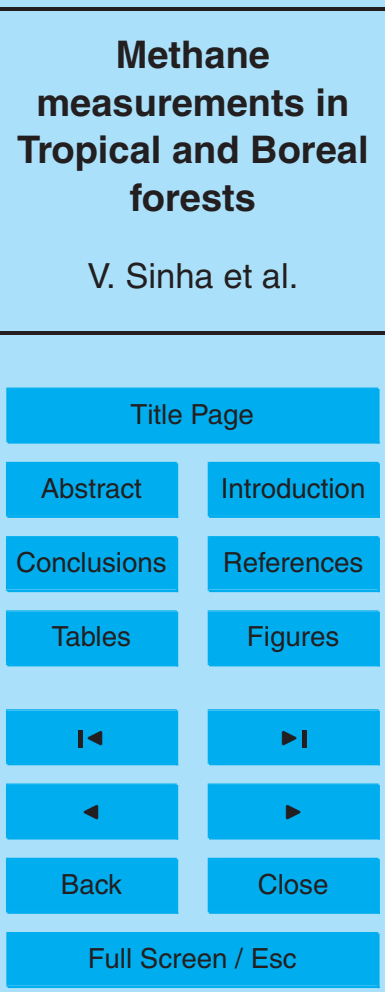

Printer-friendly Version

Interactive Discussion 


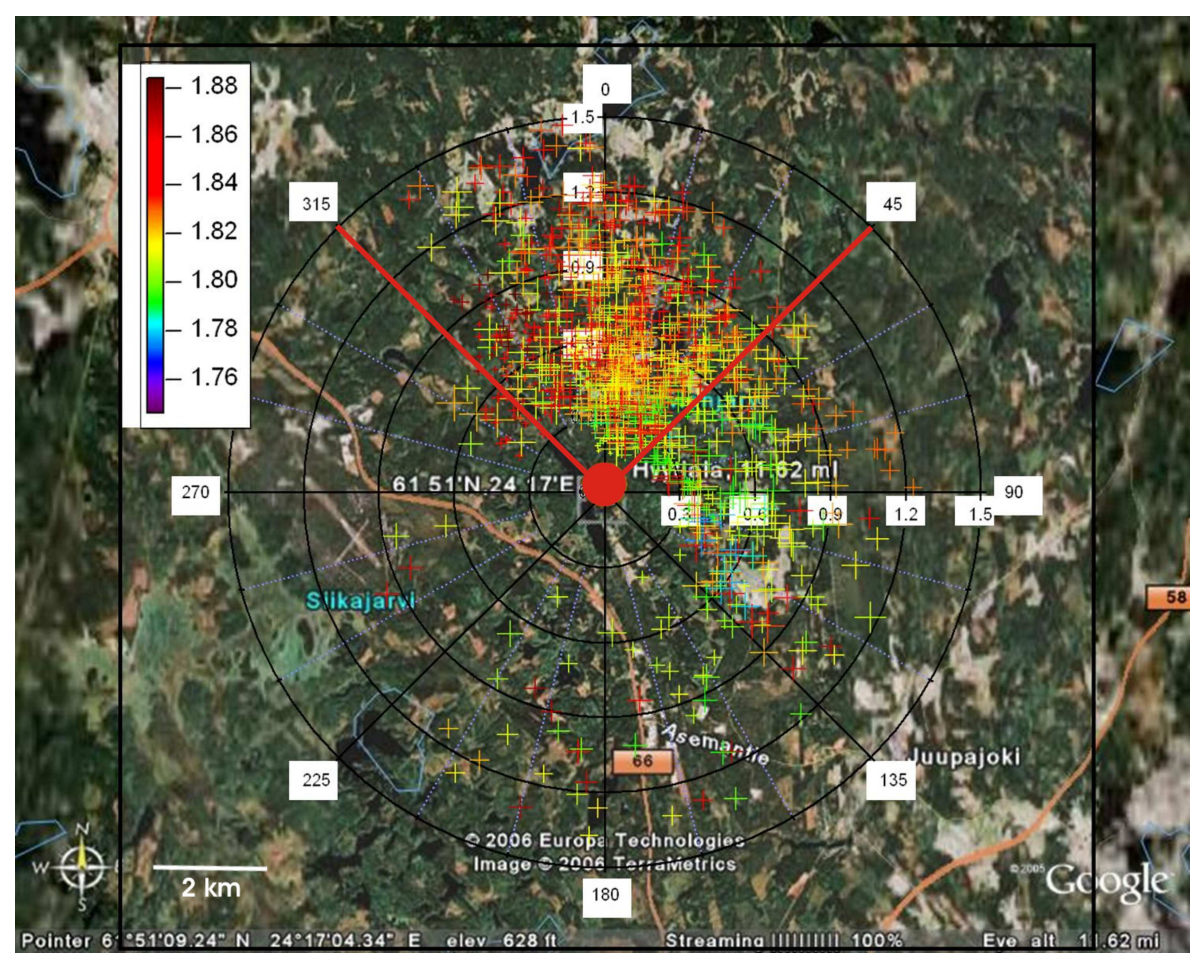

Fig. 2. Wind rose plot showing methane (coloured markers and scale), wind speed (radii) and wind direction (angle) in Hyytiäla during the campaign (Map courtesy of Google Earth ${ }^{\mathrm{TM}}$ mapping service)

\section{ACPD}

7, 14011-14039, 2007

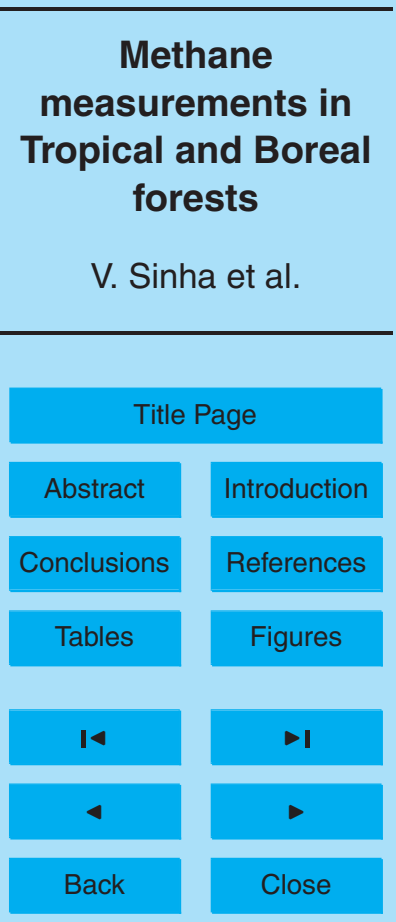

Full Screen / Esc

Printer-friendly Version

Interactive Discussion 


\section{ACPD}

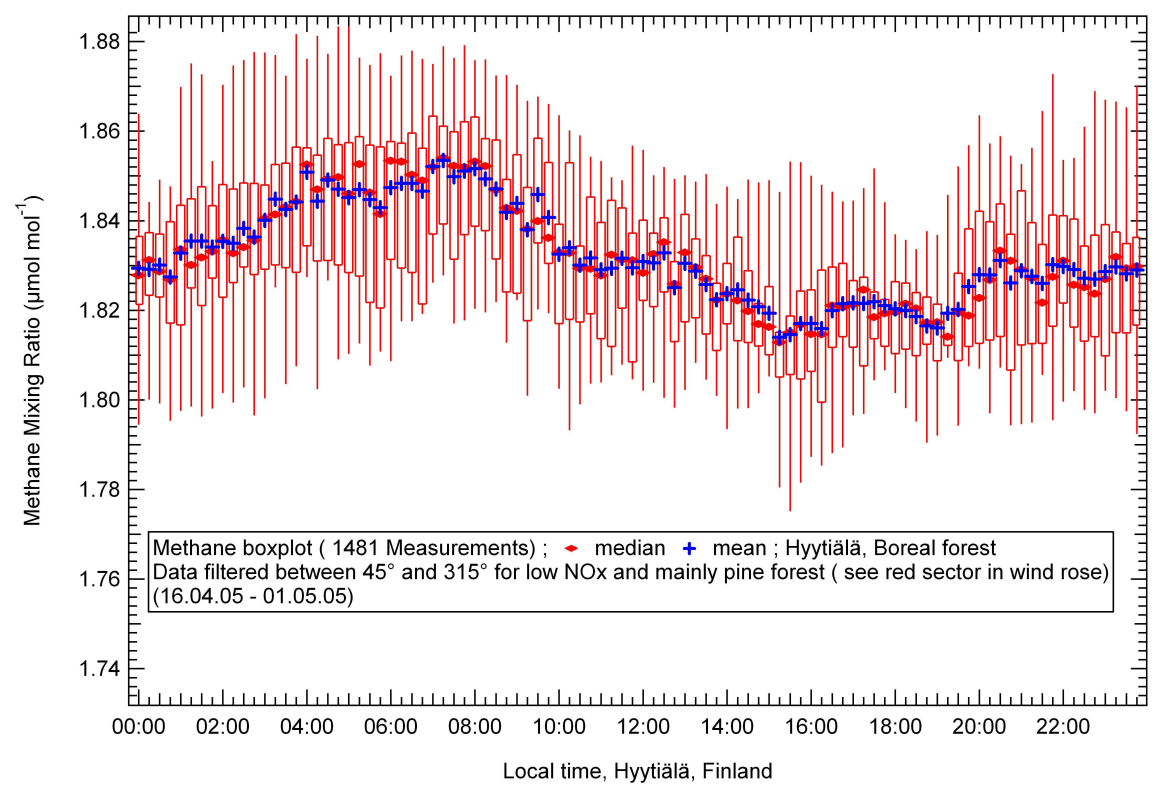

Fig. 3. Box and whisker plot for diel cycle of filtered methane data $\left(315^{\circ}-45^{\circ}\right.$ wind sector $)$ from Hyytiäla $\left(61^{\circ} 51^{\prime} \mathrm{N}, 24^{\circ} 17^{\prime} \mathrm{E}, 170 \mathrm{~m}\right.$ a.s.I.), Finland during the BACCI/QUEST III Campaign.

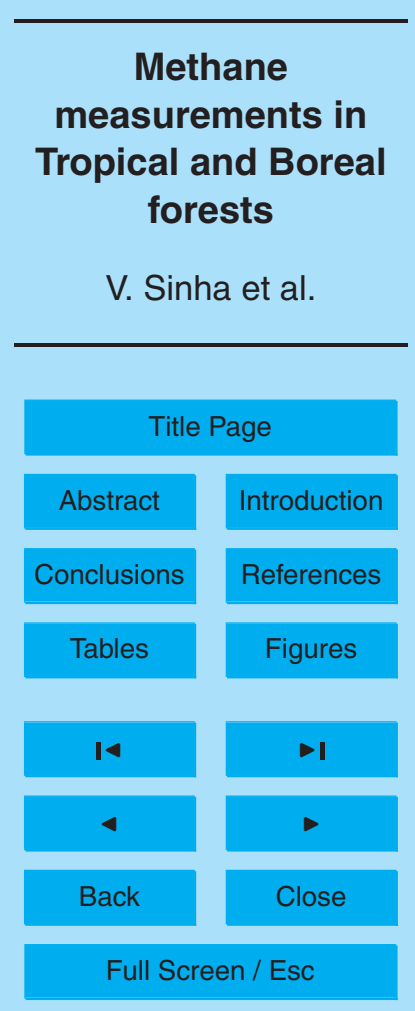

Printer-friendly Version

Interactive Discussion 


\section{ACPD}
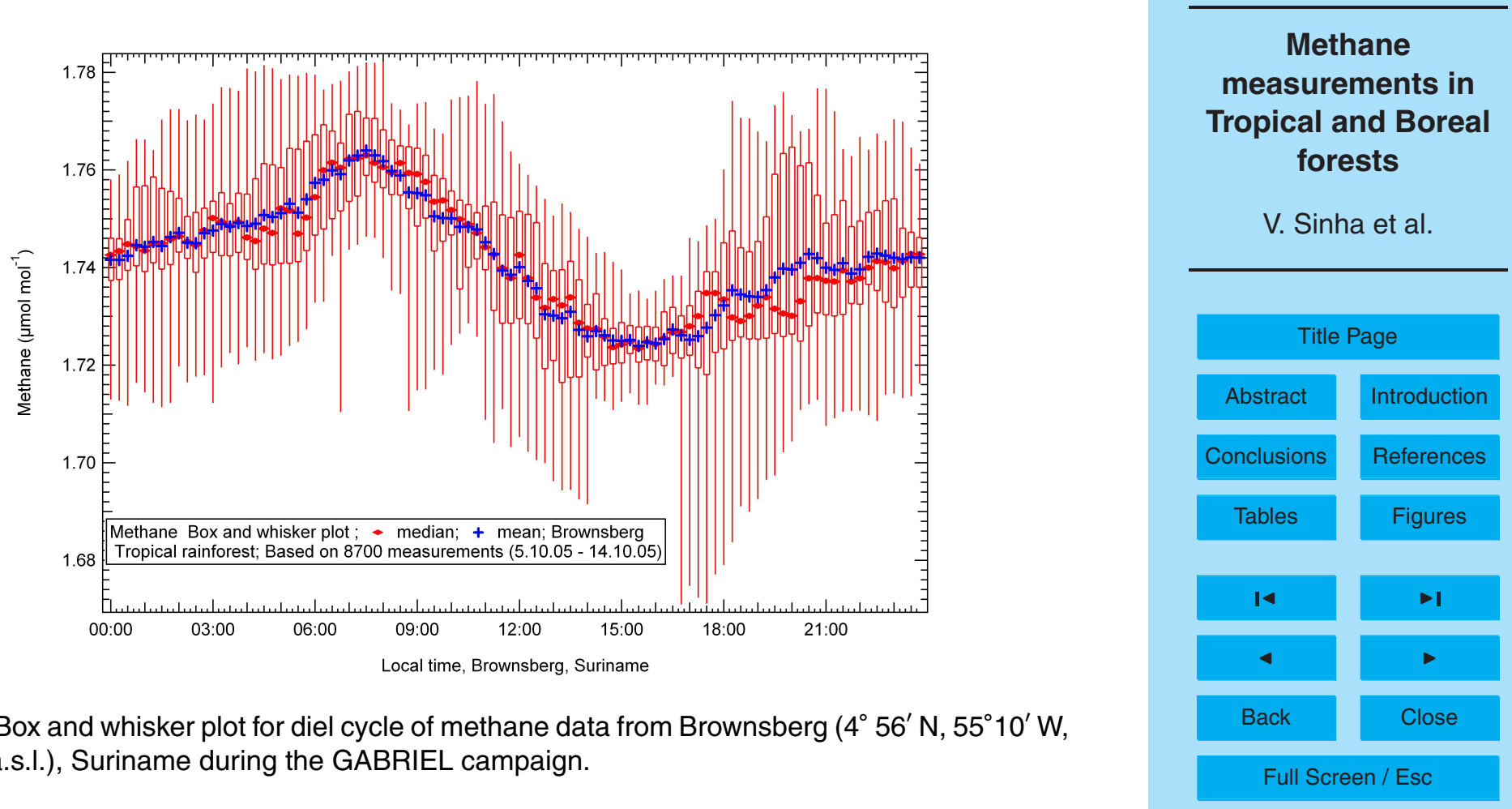

Fig. 4. Box and whisker plot for diel cycle of methane data from Brownsberg $\left(4^{\circ} 56^{\prime} \mathrm{N}, 55^{\circ} 10^{\prime} \mathrm{W}\right.$, $514 \mathrm{~m}$ a.s.I.), Suriname during the GABRIEL campaign.

Full Screen / Esc

Printer-friendly Version

Interactive Discussion 


\section{ACPD}

7, 14011-14039, 2007
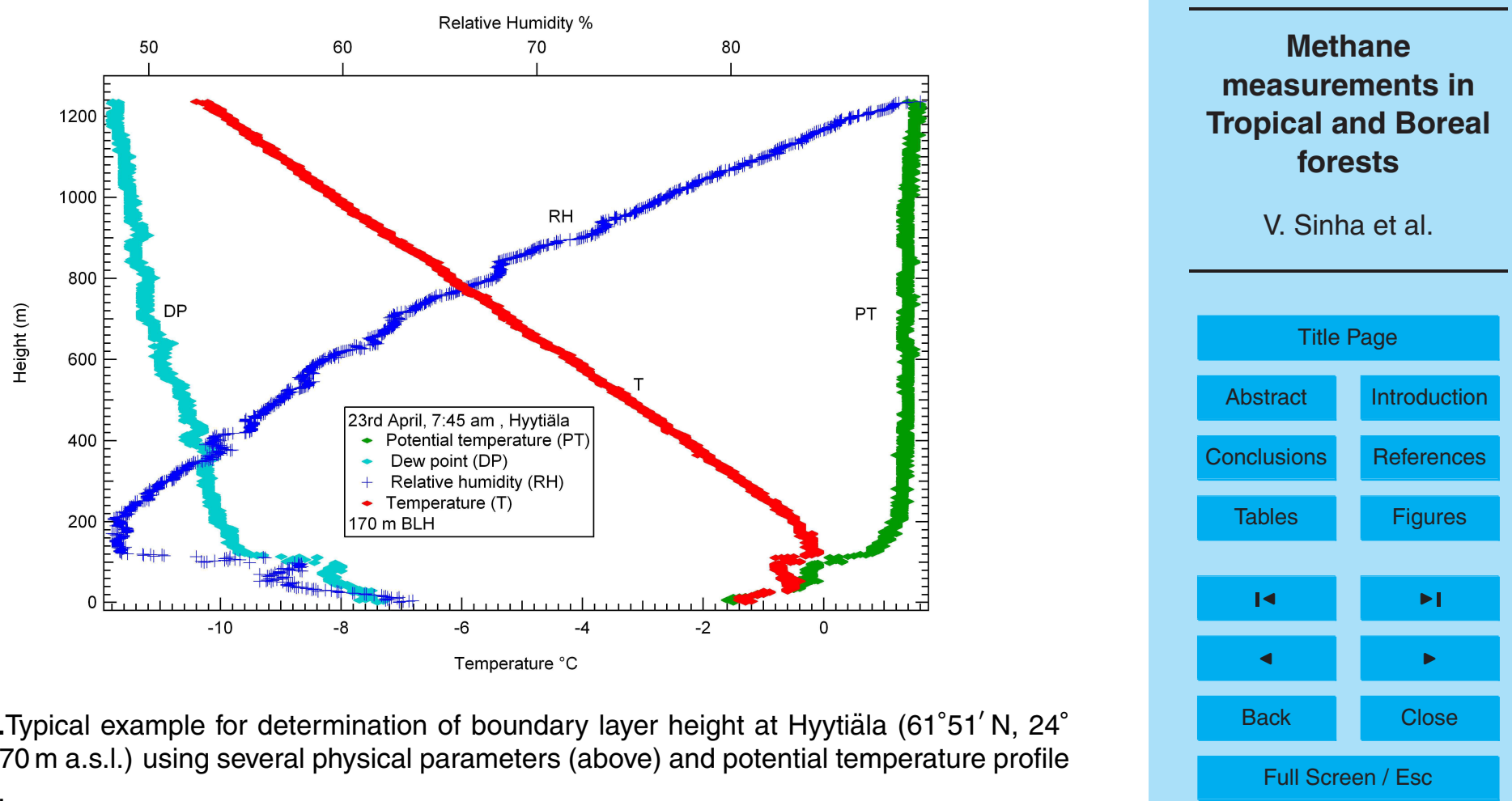

Fig. 5a.Typical example for determination of boundary layer height at Hyytiäla $\left(61^{\circ} 51^{\prime} \mathrm{N}, 24^{\circ}\right.$ $17^{\prime} \mathrm{E}, 170 \mathrm{~m}$ a.s.l.) using several physical parameters (above) and potential temperature profile (below).

Printer-friendly Version

Interactive Discussion 


\section{ACPD}

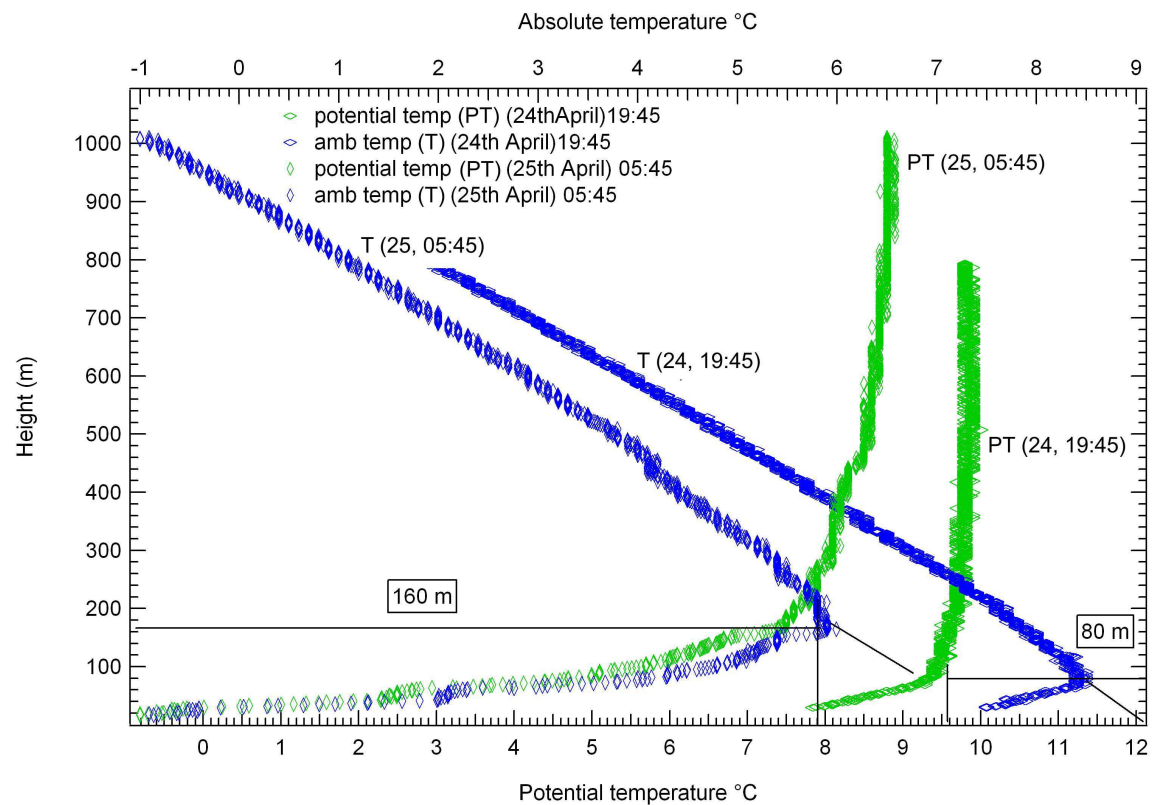

Fig. 5b.Typical example for determination of boundary layer height at Hyytiäla $\left(61^{\circ} 51^{\prime} \mathrm{N}, 24^{\circ}\right.$ $17^{\prime} \mathrm{E}, 170 \mathrm{~m}$ a.s.l.) using several physical parameters (above) and potential temperature profile (below).

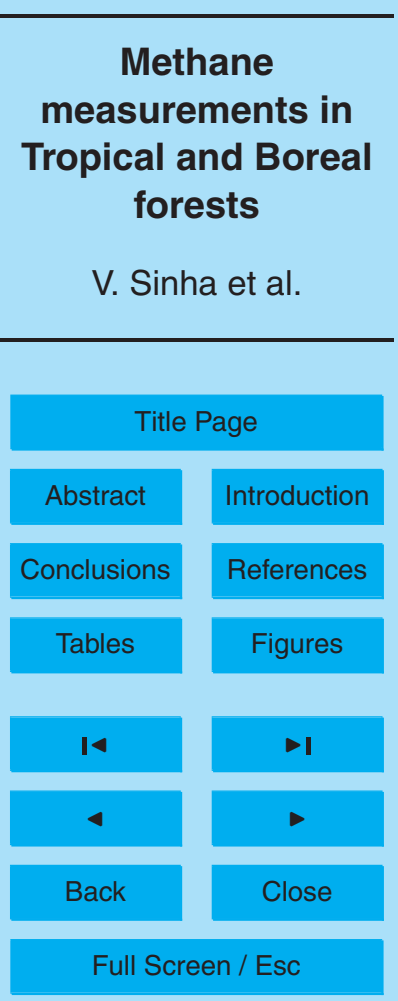

Printer-friendly Version

Interactive Discussion 


\section{ACPD}

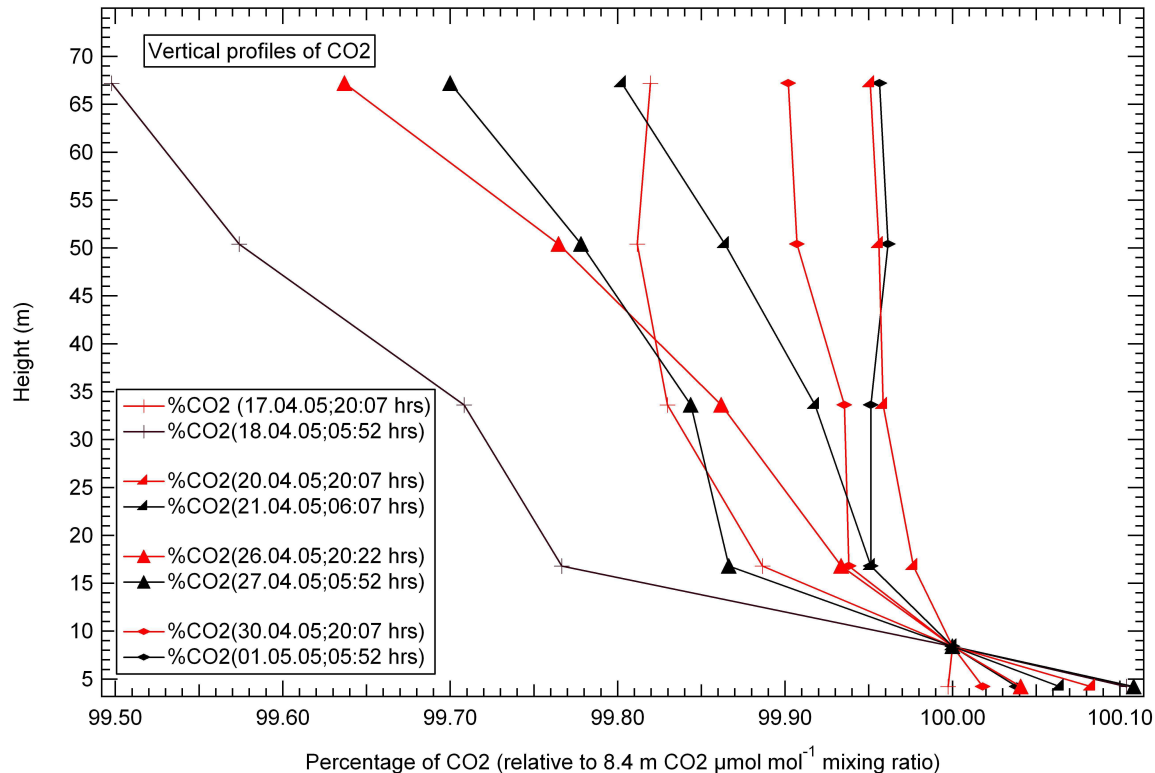

\section{7, 14011-14039, 2007}

\section{Methane measurements in Tropical and Boreal}

forests

\section{Sinha et al.}

Title Page

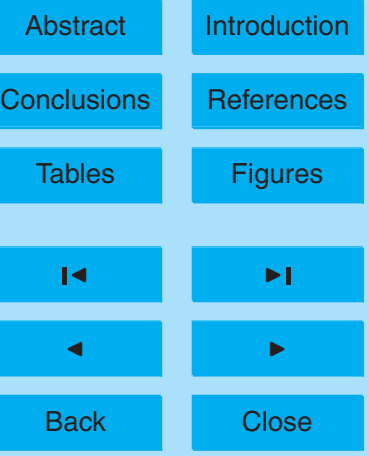

Full Screen / Esc

Printer-friendly Version

Interactive Discussion 